\title{
Hydrography, bacteria and protist communities across the continental shelf and shelf slope of the Andaman Sea (NE Indian Ocean)
}

\author{
Torkel Gissel Nielsen ${ }^{1, *}$, Peter Koefoed Bjørnsen ${ }^{1}$, Pensri Boonruang ${ }^{2}$, Michael Fryd ${ }^{3}$, \\ Per Juel Hansen ${ }^{4}$, Vudhichai Janekarn ${ }^{2}$, Vitthaya Limtrakulvong ${ }^{2}$, Peter Munk ${ }^{5}$, \\ Ole Schou Hansen ${ }^{1}$, Suree Satapoomin ${ }^{2}$, Suchat Sawangarreruks ${ }^{2}$, \\ Helge Abilhauge Thomsen ${ }^{3}$, Jette Buch Østergaard ${ }^{3}$
}

\footnotetext{
${ }^{1}$ Department of Marine Ecology, National Environmental Research Institute, Frederiksborgvej 399, PO Box 358, 4000 Roskilde, Denmark

${ }^{2}$ Phuket Marine Biological Center, PO Box 60, 83000 Phuket, Thailand

${ }^{3}$ Botanical Institute, University of Copenhagen, Øster Farimagsgade 2D, 1353 Copenhagen, Denmark ${ }^{4}$ Marine Biological Laboratory, University of Copenhagen, Strandpromenaden 5, 3000 Helsingør, Denmark ${ }^{5}$ Department of Marine Ecology and Aquaculture, Danish Institute for Fisheries Research, Kavalergaarden 6 ,
} 2920 Charlottenlund, Denmark

\begin{abstract}
The hydrography and plankton community structure was investigated in the Andaman Sea off Phuket, Thailand. Two cruises were conducted in 1996, one representing the calm dry NE monsoon season (March) and the other representing the stormy and rainy SW monsoon season (August). Sampling was performed along 3 transects perpendicular to the shelf break, from the coast across the shelf into deep water. The water column at the nearshore stations was vertically mixed, while the water column at off shore stations was strongly stratified, hence a frontal zone was established at the mid shelf. A prominent feature of the area was the pronounced internal wave centred around the pycnocline. The wave was observed from the outermost stations to the mid-shelf front. The height of the wave reached peak values of approximately $60 \mathrm{~m}$ in areas of approximately $300 \mathrm{~m}$ bottom depth. At all stations in stratified waters the vertical distribution of the phytoplankton showed a pronounced subsurface chl a peak in association with the pycnocline. The highest chl $a$ values and primary production was observed at the front established at the mid shelf where the pycnocline meets the bottom, and salt nutrient-rich water is mixed up in the surface layer. We did not find any relationships between hydrography and the other key components of the microbial food web. No difference in productivity or food web structure was observed between the 2 seasons despite a significant difference in climatic forcing. Pico- and nanoplankton dominated the biomass in both seasons and Synechococcus contributed 72 to $74 \%$ of the biomass. Analysis of the microbial food web and establishment of carbon-flow budgets illustrates the importance of the microbial food web for making the primary producers available to the higher trophic levels.
\end{abstract}

KEY WORDS: Tropical ecology · Internal wave $\cdot$ Biological oceanography $\cdot$ Bacteria $\cdot$ Microbial foodweb

Resale or republication not permitted without written consent of the publisher

\section{INTRODUCTION}

Tropical oceans cover ca. $40 \%$ of the global ocean (Longhurst \& Pauly 1987); however, knowledge of the structure and function of tropical pelagic ecosystems is limited, compared to information available on arctic and temperate pelagic ecosystems. In contrast to high latitude ecosystems, the tropics are characterised by smaller seasonal amplitudes in the climatic forcing factors. Despite the apparent stability of tropical seas, major seasonal oscillations occur due to, e.g. the influence from monsoonal forcing. The mon- 
soons potentially have a great impact on mixed layer depth, on the flux of nutrients to the upper mixed layer and thereby on pelagic food web structure and production.

Recently, a number of multidisciplinary research programmes have been studying the dynamics of the tropical Arabian Sea (Krishnaswami \& Nair 1996, Smith et al. 1998, Burkill 1999, Garrison et al. 2000, Kidwai \& Amjad 2000). The overall aim of these investigations was to understand the linkages between large-scale pulsed atmospheric forcing, oceanic circulation patterns and episodic biological display. The research conducted in the Arabian Sea has significantly improved our knowledge and understanding of the seasonal and spatial variability of oceanographic features and the biogeochemical cycling of a tropical ocean due to monsoonal forcing.

Similar to the Arabian Sea, the western coast of Thailand is influenced by the biannual monsoon cycle that impacts the entire region from West Africa to South East Asia (Yesaki \& Jantarapagdee 1981). In the Andaman Sea the climate is influenced by 2 distinct monsoon periods, i.e. the Northeast (NE) monsoon and the Southwest (SW) monsoon. During the dry, relatively calm, NE monsoon from November to April, winds from Northeast dominate, while the SW monsoon is characterised by higher precipitation and stronger winds from the Southwest.

Since the shelf area off the Andaman Sea is an important fishing ground (Janekarn \& Hylleberg 1989), knowledge is needed regarding the influence that the monsoonal cycle and oceanographical features have on the structure and productivity of the pelagic food web supporting the fish stocks. Yesaki \& Jantarapagdee (1981) suggest that coastal upwelling is a recurrent phenomena generated by the monsoon system. Previous investigations in the Andaman Sea (Wium-Andersen 1977, Kiørboe et al. 1991) have suggested that the shelf-break front is highly productive and potentially important for the productivity of the area. Hitherto, investigations of the food web structure of the Andaman Sea have primarily covered nearshore areas and only the components of the classical food web, i.e. addressing site-specific primary production (Wium-Andersen 1977, Sundström et al. 1987, Janekarn \& Hylleberg 1989), taxonomy of the larger phytoplankton (e.g. Gedde 1996, 1999), abundance and taxonomic composition of zooplankton (Boonruang 1985, Satapoomin 1999, Satapoomin \& Pornchai 2002), and fish larvae (Janekarn \& Kiørboe 1991). Knowledge of the small-sized fractions in terms of ecological importance is limited, although a number of publications dealing with nano-sized taxa exist from the area (e.g. Thomsen \& Moestrup 1983, Thomsen \& Boonruang 1983a,b, 1984, Thomsen 1988).
During the last decades the importance of autotrophic picoplankton (i.e. $<2 \mu \mathrm{m}$ ), bacteria and heterotrophic protists have been demonstrated, and particularly so in oligotrophic warm oceans (Sorokin et al. 1985, Buck et al. 1996, Garrison et al. 1998, 2000). Since copepods are seldom able to directly capture the dominating primary producers in the oligotrophic tropical systems (Hansen et al. 1994, Calbet \& Landry 1999), the microbial food web performs a crucial role in the transfer of energy up the food chain. Obviously, knowledge of these major food web components is of considerable importance for understanding the site-specific biogeochemical characteristics and, hence, is also a prerequisite for the development of reliable strategies for sustainable regional ecosystem management.

Observations of high productivity at the shelf break in the Andaman Sea (Kiørboe et al. 1991) led to the hypothesis that the shelf break is an important site of primary and secondary production, hence a potential area for the development of a pelagic fishery. In order to further investigate this hypothesis and to improve our understanding of the tropical pelagic ecosystem, the project 'Pelagic Andaman Sea structure, function and productivity with particular emphasis on an access of potential fisheries resources' was initiated under a Thai-Danish scientific co-operation program. During these investigations we used a holistic ecosystem approach with simultaneous measurements of hydrographic parameters and key components of the pelagic food web.

Here, and in a paper by Munk et al. (2004, this volume), we provide an overall outline of the hydrography and the pelagic ecosystem of the Andaman Sea. Special emphasis is given to seasonal and horizontal distributional patterns of plankton components in relation to monsoonal cycles and physical parameter changes. The present paper targets hydrographical features and bacterial and protist plankton along transects from the coastal shallow water across the shelf slope into the offshore waters, while the paper by Munk et al. (2004) addresses the assemblages of mesozooplankton and fish larvae.

Other related papers provide an in-depth analysis of selected trophic entities and processes of the Andaman Sea, i.e. phytoplankton (J. B. Østergaard, H. A. Thomsen, F. Riget unpubl.), microprotozoa (P. J. Hansen \& T. G. Nielsen unpubl.) and copepods (Satapoomin et al. 2004, this volume).

\section{MATERIALS AND METHODS}

Study area. Two cruises were conducted from March 11 to March 27 (NE-96) and August 15 to August 29 1996 (SW-96) on board the RV 'Chakratong Tongyia' (Fig. 1). Sampling was performed during the daytime 
along 3 transects, numbered 1 to 3 from south to north, perpendicular to the shelf break and extending from the coast across the shelf slope (Fig. 1). The distance between stations was 5 or $10 \mathrm{~nm}$. The shelf is ca. $30 \mathrm{~km}$ wide at Transect 1 and widens to ca. $90 \mathrm{~km}$ at the northernmost Transect 3. At Transect 1, the depth increases steeply just off the coast and the near shore station was located at a depth of $60 \mathrm{~m}$. Nearshore stations on the 2 other transects were at $20 \mathrm{~m}$ depth. The original idea of repeating identical sampling programmes during March (NE monsoon) and August (SW monsoon) was not fully achieved, due to very strong winds prevailing in August. The 2 southernmost transects and only the nearshore stations on Transect 3 were revisited during the August cruise (Fig. 1).

Water column structure. At all sta-

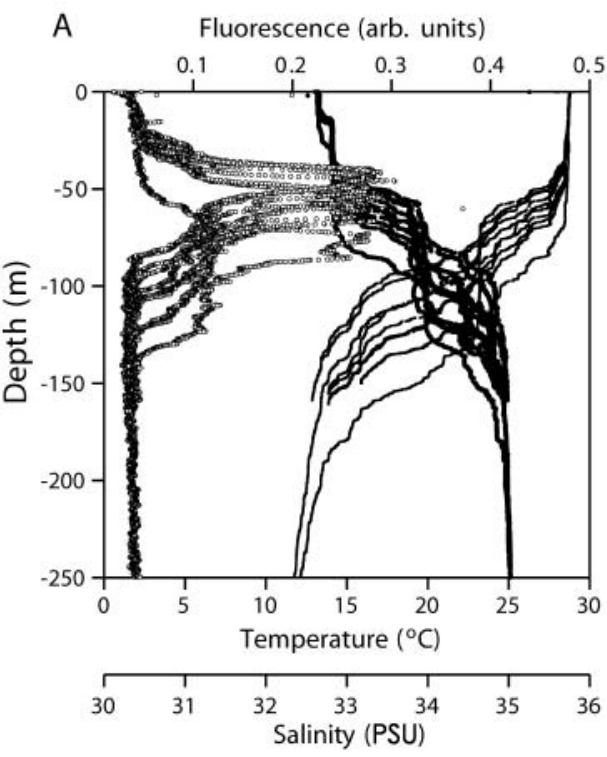
B Fluorescence (arb. units)

Fig. 2. (A) The 5 successive CTD casts from Stn 12 on Transect 2 SW-96 during the passage of an internal wave packet, exemplifying the impacts of the internal wave on vertical characteristics of salinity (PSU), temperature $\left({ }^{\circ} \mathrm{C}\right.$ ) and fluorescence (arb. units).

(B) The same profile after the averaging procedure has been applied tions the vertical distribution of temperature, salinity and fluorescence was measured with a Sea-Bird SBE 25-01 Sealogger CTD (conductivitytemperature-depth) equipped with a Chelsea fluorometer. Due to a pronounced internal wave in the pycnocline, 5 consecutive CTD casts (each consisting of a down-cast and an upcast) were carried out at each station with the aim of sampling the full extent of the

wave; Fig. 2A exemplifies the very dynamic nature of the water column structure. To standardise the profiles, the water column parameters of the 5 CTD casts were averaged within depth intervals of $1 \mathrm{~m}$ (exemplified in Fig. 2B) prior to the isoplet contouring of density and fluorescence. Water column density profiles were used to calculate the stratification parameter $\phi$, according to Simpson (1981). This gives a mea-

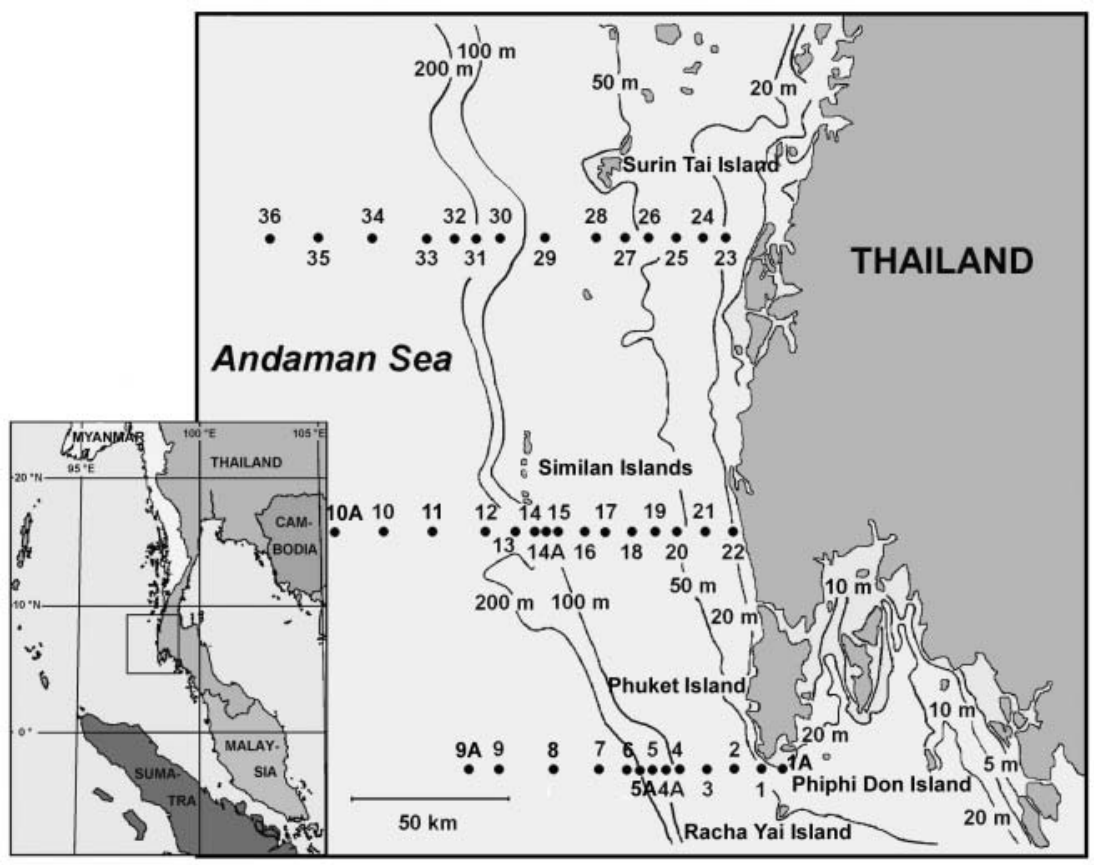

Fig. 1. Study area and approximate position of transects (1 to 3, south to north) sampled sure of the mechanical work required to mix the water column $\left(\mathrm{J} \mathrm{m}^{-3}\right)$ :

$$
\phi=g / h \int_{-h}^{0}\left(p-p_{0}\right) z \cdot \mathrm{d} z
$$

where $g=$ acceleration due to gravity, $h=$ total depth of the water column, $p=$ density, $p_{0}=$ average density of the water column, and $z=$ depth.

In addition to the stratification parameter, we defined and calculated a wave intensity index (max amplitude ${ }^{3} /$ depth). We calculated the height of the internal wave from a comparison of the successive CTD profiles, as the maximum depth minus minimum depth of a water mass of a given density. The calculated wave height was then plotted against the average depth of the density being considered (Fig. 3).

The relative chlorophyll fluorescence values were converted to chl a from a linear regression between the fluorescence (Fluo) and spectrophotometric 


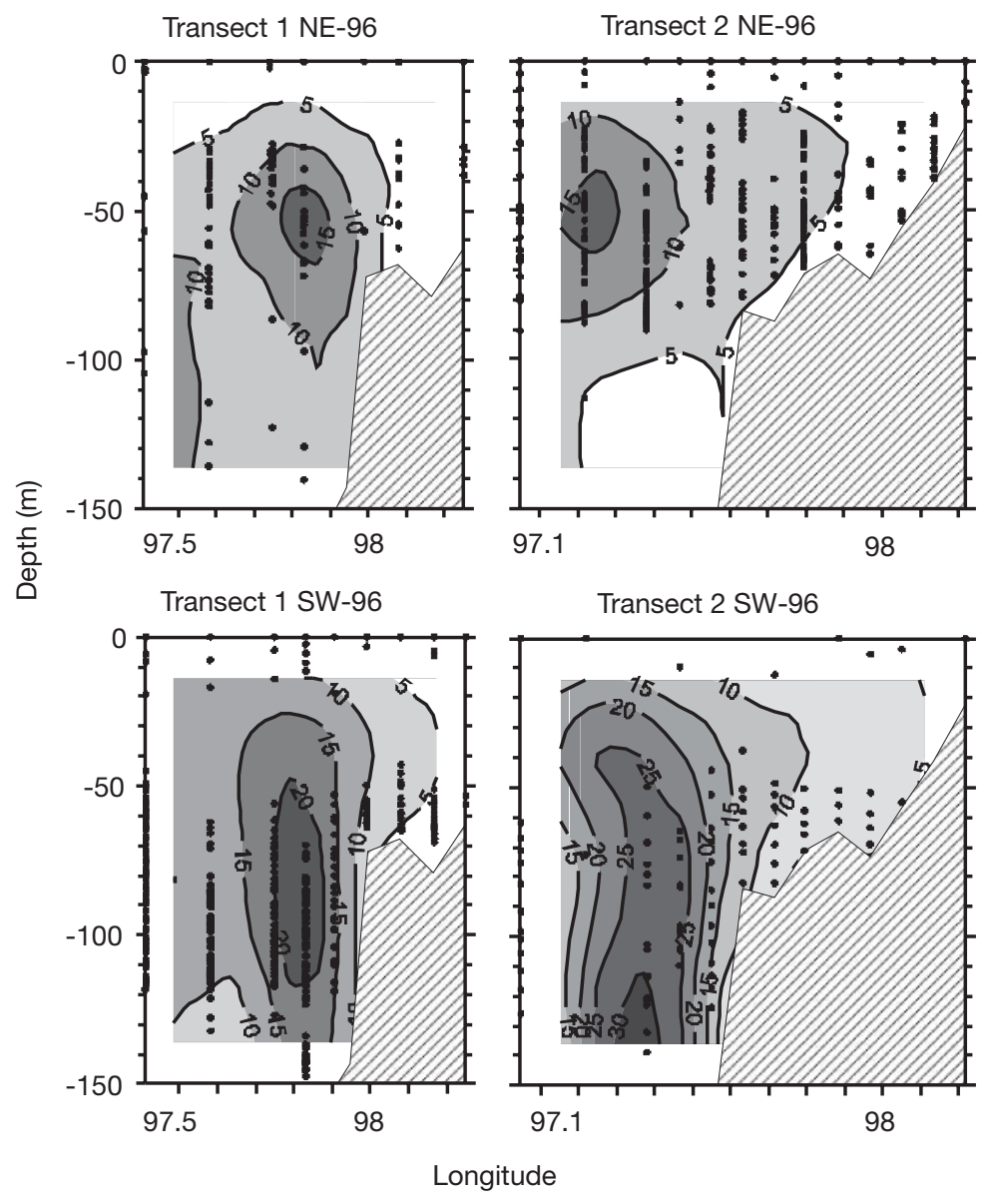

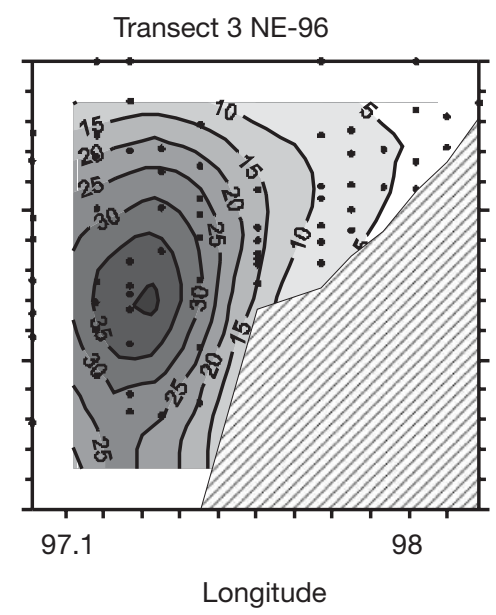

Fig. 3. Contour plots of the height (m) of the internal wave along each transect during the March (NE-96) and August (SW96) cruises; the dots indicate the calculated values. Wave height was calculated from the CTD profiles as maximum depth minus minimum depth of a given density, plotted against the average depth of the density under consideration measurements of chl $a$ covering all transects (chl $a=$ Fluo/0.6506-0.012, $\mathrm{r}^{2}=0.83, \mathrm{n}=113$ ). Solar irradiation was measured on-deck every half hour between sunrise and sunset with a Li-cor irradiance meter.

Water bottle sampling. According to water depth and vertical distribution of fluorescence, 3 to 7 depths were selected for water sampling using 81 Niskin water bottles. All samples for chemical and biological measurements were taken from the same water bottle.

Nutrients: $100 \mathrm{ml}$ samples for nutrients $\left(\mathrm{NO}_{2}{ }^{-}, \mathrm{NO}_{3}{ }^{-}\right.$ and $\mathrm{PO}_{4}{ }^{3-}$ ) were taken from all depths and frozen $\left(-18^{\circ} \mathrm{C}\right)$ immediately and later measured spectrophotometrically according to Strickland \& Parsons (1968).

Particulate organic carbon (POC): $1000 \mathrm{ml}$ samples were filtered onto precombusted Whatman GF/F filters for analysis of the POC concentration. The filters were kept deep-frozen $\left(-18^{\circ} \mathrm{C}\right)$ for a period of ca. $3 \mathrm{wk}$, dried in an oven for $24 \mathrm{~h}$ at $60^{\circ} \mathrm{C}$ and again kept deep-frozen until analysis. The samples were analysed in a Carlo Erba Elemental Analyzer (EA 1108).

Phytoplankton biomass and composition: For chl a measurement, a $1000 \mathrm{ml}$ sample was filtered onto Whatman GF/F filters. A small amount of $\mathrm{MgCO}_{3}$ in saturated aqueous solution was added during filtra- tion. The filters were homogenised and the pigments extracted in $90 \%$ acetone. Chl a was determined spectrophotometrically following Jeffrey \& Humphrey (1975).

Phytoplankton species composition: A subset of stations was used for phytoplankton analyses. Samples were taken at up to 4 depths $(5 \mathrm{~m}$, depth of maximum flourescence [FM], 80 and $200 \mathrm{~m}$ ) depending on water depth. Nanoplankton (2 to $20 \mu \mathrm{m}$ ) and autotrophic picoplankton $(<2 \mu \mathrm{m})$ were enumerated by epifluorescence microscopy while larger phytoplankton was quantified using inverted microscopy. For epiflourescence microscopy, samples were stained with proflavine (Haas et al. 1982). For each sample $40 \mathrm{ml}$ of seawater was stained with $100 \mu \mathrm{l}$ of proflavine, and after 2 min it was fixed with $2 \mathrm{ml}$ of $25 \%$ glutaraldehyde, and within $24 \mathrm{~h}$ filtered onto black $0.2 \mu \mathrm{m}$ polycarbonate filters and rinsed with demineralized water. The dry filters were mounted in parafin oil on microscope slides and stored in the refrigerator for later examination. In the laboratory, a minimum of 400 nanoplankton cells and >500 autotrophic picoplankton cells (incl. Synechococcus) were enumerated using an Olympus $\mathrm{BH} 2$ epifluorescence microscope. Cell volume was 
estimated from length and width measurements of 10 cells from each nanoplankton category per filter and converted to carbon using volume-sensitive carbon regressions for flagellates and diatoms (Eppley et al. 1970). A constant carbon per cell estimate (250 fg C cell $^{-1}$ ) was used for Synechococcus (Campbell et al. 1994). A $500 \mathrm{ml}$ sample for enumeration of the larger phytoplankton $(>20 \mu \mathrm{m})$ was fixed in $2 \%$ Lugol (final concentration). Because of the very low concentration of the larger phytoplankton, the samples were concentrated to a final volume of ca. $50 \mathrm{ml}$ prior to identification and enumeration using an inverted microscope according to Utermöhl (1958). Organisms were sized, converted to biovolume assuming simple geometric forms and subsequently to carbon using the carbon conversions in accordance with Edler (1979) for diatoms, dinoflagellates and cyanobacteria.

Primary production: Samples for primary production were kept in dim light until transfer to $25 \mathrm{ml}$ acidwashed Pyrex incubation bottles. Two $\mu \mathrm{Ci}$ of a $\mathrm{NaH}^{14} \mathrm{CO}_{3}$ solution were added to each of the incubation bottles. Incubation was conducted in a laboratory incubator; PI-curves (photosynthesis [P], irradiance [I]) were established for the phytoplankton community in the surface $(5 \mathrm{~m})$ and at the depth of maximum fluorescence. Bottles were incubated at 0 (dark in duplicates), $3,7,13,25,50$ and $100 \%$ (triplicate) of full incubator irradiance. Duplicate surface samples were exposed to natural sunlight (on deck). For 3 additional depths, duplicate full light bottles and 1 dark bottle were incubated. After $2 \mathrm{~h}$ incubation the light was dimmed and the samples immediately filtered onto $0.45 \mu \mathrm{m}$ cellulose nitrate filters. One drop of $0.1 \mathrm{~N} \mathrm{HCl}$ with $5 \%$ formalin was added on each filter and the filters were transferred to plastic vials and refrigerated. In the laboratory a $4 \mathrm{ml}$ scintillation cocktail was added to each vial (Packard Ultima Gold). After $8 \mathrm{~h}$ the samples were mixed and counted on a Packard scintillation counter. Net DPM values were converted into $\mathrm{C}$ assimilation rates assuming a DIC concentration of $25 \mathrm{mg} \mathrm{Cl}^{-1}$ and further to specific primary productivity (SPP $\mu \mathrm{g} C \mu \mathrm{g}$ chl $a^{-1} \mathrm{~h}^{-1}$ ) by division with the measured chlorophyll concentration in the sample. SPP values were plotted against irradiance (I) and fitted by non-linear regression to an exponential saturation function $\mathrm{SPP}=P_{\max }$ $(1-\exp (-\alpha \times I))$. PI parameters $\left(P_{\max }\right.$ maximum photosynthesis rate, and $\alpha$, light utilisation coefficient) were estimated for all depths by linear extrapolation of values from the 2 measured depths. For each depth and hour, in situ light was estimated from surface irradiance measurements fitted to a parabolic function of time and measurements of light attenuation with depth. In situ SPP was then estimated for each depth and clock hour from the estimated in situ irradiance and the estimated $P_{\max }$ and alpha values for the given depth. In situ pri- mary production was calculated by multiplication with the estimated average chlorophyll concentration (over the course of the internal wave) and integrated over time and depth.

Bacterioplankton biomass and production. Bacterial abundance: Samples were taken at $5 \mathrm{~m}, 15 \mathrm{~m}, \mathrm{FM}$, $80 \mathrm{~m}$ and just above the bottom (AB). For the deep stations AB was replaced by a $100 \mathrm{~m}$ sample. For estimation of bacterioplankton biomass, samples were stained with acridine orange (Hobbie et al. 1977). Forty $\mathrm{ml}$ of seawater was fixed with $2 \mathrm{ml} 25 \%$ glutaraldehyde. Within $24 \mathrm{~h}$, a $5 \mathrm{ml}$ sample was filtered onto black $0.2 \mu \mathrm{m}$ polycarbonate filters. When the filters were dry, they were stained with acridine orange for 2 min and rinsed with demineralized water (Hobbie et al. 1977). The dry filters were placed in a stamp collection folder and stored frozen. In the laboratory, a minimum of 400 cells were enumerated on each filter using an Olympus BH-2 epifluoresence microscope. Cell volumes were estimated from length and width measurements of 50 cells per filter and the volumes were converted to carbon using the power function as suggested by Simon \& Azam (1989).

Bacterial production: Bacterial growth rate were measured from ${ }^{3} \mathrm{H}$-thymidine incorporation according to Fuhrman \& Azam (1980). Triplicate $10 \mathrm{ml}$ seawater samples had $100 \mu \mathrm{l} 250 \mathrm{nM}{ }^{3} \mathrm{H}$-thymidine added to each and incubated for $30 \mathrm{~min}$. Incubation was stopped by adding $100 \mu \mathrm{l} 25 \%$ formaldehyde. One additional blank sample had $100 \mu \mathrm{l} 25 \%$ formaldehyde added before adding ${ }^{3} \mathrm{H}$-thymidine. Samples were refrigerated and within $24 \mathrm{~h}$ filtered onto Whatman cellulosenitrate filters $(0.45 \mu \mathrm{m})$ on a filtration unit with cold steel cylinders. Once filters were dry they were rinsed with cold $0.1 \mathrm{~N} \mathrm{HCl}$. The dry filters were transferred to plastic mini-vials and stored refrigerated. ${ }^{3} \mathrm{H}$-thymidine incorporation was analysed by scintilation-counting within $1 \mathrm{wk}$ of the cruise. The incorporated ${ }^{3} \mathrm{H}$ thymidine was converted to cell production using a factor of $1.1 \times 10^{18}$ cells mol$^{-1}$ thymidine incorporated (Riemann et al. 1987).

Protozooplankton. A $500 \mathrm{ml}$ water sample for enumeration of heterotrophic/mixotrophic protozoa was fixed in $1 \%$ Lugol's solution (final concentration). A subsample of 50 or $100 \mathrm{ml}$ was counted after $24 \mathrm{~h}$ of sedimentation using an inverted microscope. Depending on abundance of the species in consideration, a fraction of, or the total sample, was counted. The biomass of the heterotrophic dinoflagellates $<20 \mu \mathrm{m}$ was estimated using the proflavine-stained filters prepared for the nanoflagellates (see above). Biovolumes of the cells were estimated from measurements of linear dimensions assuming simple geometrical shapes. The volume to carbon conversion factors used were $0.11 \mu \mathrm{g} \mathrm{C} \mu \mathrm{m}^{-3}$ for ciliates and naked dinoflagellates 
and $0.13 \mu \mathrm{g} \mathrm{C} \mu \mathrm{m}^{-3}$ for thecate dinoflagellates (Edler 1979). Biovolumes of heterotrophic dinoflagellates $<20 \mu \mathrm{m}$ were converted to carbon using volume sensitive carbon regressions (Eppley et al. 1970).

Depth integration. To compare the productivity across the shelf area of the Andaman sea, all biological data were converted to biomass per unit area $\left(\mathrm{m}^{-2}\right)$. Since no major differences were observed between the transects, all biological data are presented against bottom depth, assuming that this parameter gives the best description of the site-specific physical forcing. The biomass of the discrete samples of phytoplankton, bacteria, heterotrophic nanoflagellates and microprotozooplankton ( 3 to 5 depths per station) and chl a fluorescence (50 to 200 measurements) were transformed by trapezoidal integration to (1) a depth of $100 \mathrm{~m}$ representing the lower limit of the photic zone, $1 \%$ light depth, or (2) the actual bottom at the shallower stations.

\section{RESULTS}

\section{The solitons}

A characteristic oceanographic feature of the Andaman Sea is the occurrence of high amplitude solitons in the pycnocline (internal waves). During our cruises surfacs 'fingerprints' of the solitons were evident. When we sailed along the transects, the passing wave packets could be seen as repeated patterns of surface 'oily slicks' and wave bands 'ripes'. The height of the soliton peaked at the depth of the pycnocline (Fig. 3) and was horizontally most pronounced at the shelf slope at 250 to $350 \mathrm{~m}$ depth, where wave heights reached up to $65 \mathrm{~m}$ (Fig. 3). When the soliton wave packets passed onto the shallow shelf, the height of the waves was dampened (Fig. 3).

\section{Water column structure}

The surface water was between 28 and $29^{\circ} \mathrm{C}$ and 32.8 to 33 PSU. Below the pycnocline, here defined by the $1021.5 \mathrm{~kg} \mathrm{~m}^{-3}$ isopycnal, the water temperature decreased to below $14^{\circ} \mathrm{C}$ and the salinity increased to $35 \mathrm{PSU}$ at depths $>250 \mathrm{~m}$ (Fig. 2). Between the 2 cruises the average depth of the pycnocline was eroded from $34 \pm 2 \mathrm{~m}$ in March to $62 \pm$ $2 \mathrm{~m}$ in August (Fig. 4). The water column at the near shore station was vertically well mixed while the column at the deeper stations were strongly stratified (Figs. 4 \& 5). In general, the stratification index showed the same trend along all transects; the water column off the shelf break was strongly stratified,
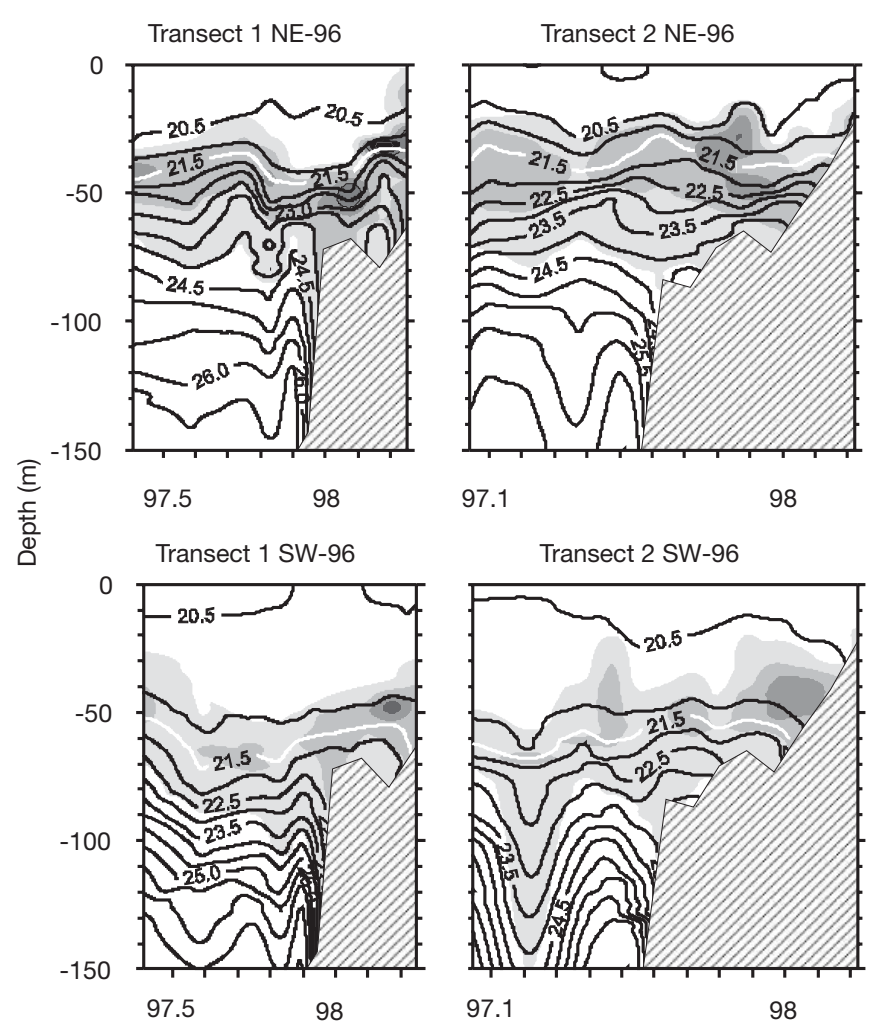

97.1

98

Transect 2 SW-96

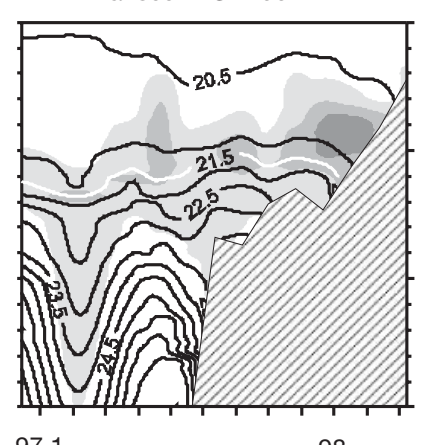

97.1

98
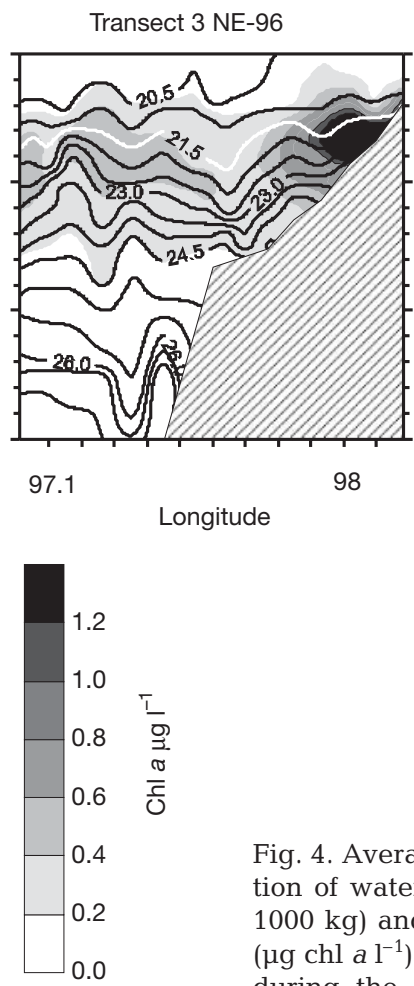

Fig. 4. Average vertical distribution of water density (sigma- $t+$ $1000 \mathrm{~kg}$ ) and chl a fluorescence

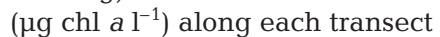
during the March and August cruises. The white line illustrates the pycnocline at $1021.5 \mathrm{~kg} \mathrm{~m}^{-3}$ 

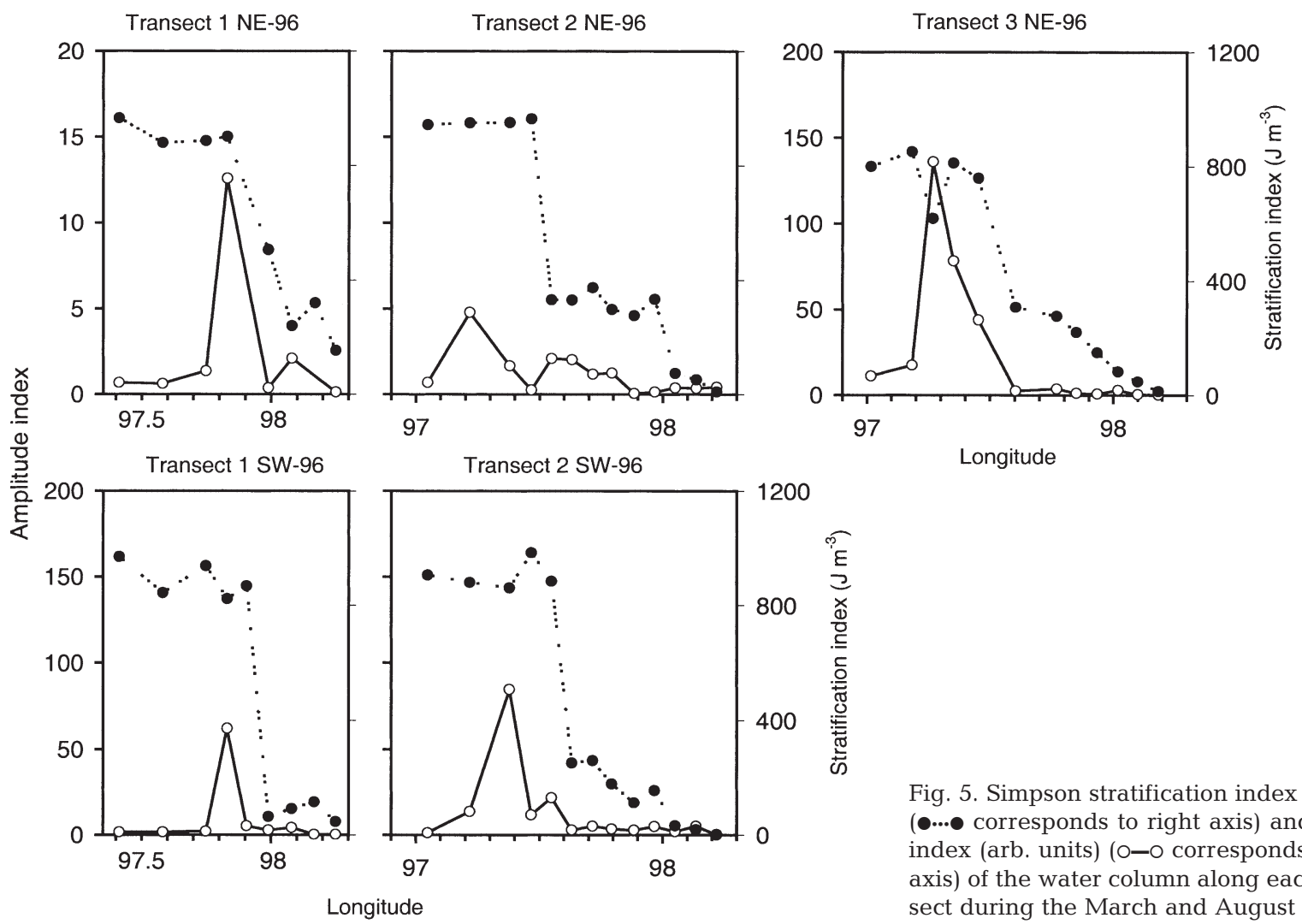

Fig. 5. Simpson stratification index $\left(\mathrm{J} \mathrm{m}^{-3}\right)$ (๑... corresponds to right axis) and wave index (arb. units) ( $\bigcirc-\circ$ corresponds to left axis) of the water column along each transect during the March and August cruises

while the intensity of stratification decreased over the shallow mid-shelf (Fig. 5). At midshelf the pycnocline meets the bottom and a frontal zone is established (Figs. 4 \& 5). During the August cruise (SW-96), the stratification at the shelf stations were weaker, probably due to more intense winds and the erosion of the pycnocline. In accordance with internal wave height observations (Fig. 3), the wave intensity index peaked at the lower shelf break at 250 to $350 \mathrm{~m}$ depth (Fig. 5).
The vertical distribution of inorganic nutrients reflected the water column structure. A depletion of nitrate in the surface layer was evident during both seasons, where the concentration was $<0.1 \mu \mathrm{M}$ in the upper $25 \mathrm{~m}$ during March and $50 \mathrm{~m}$ during August (Fig. 6A). The nitracline deepened along with the erosion of the pycnocline from 30 to ca. $60 \mathrm{~m}$ from March to August. Across the pycnocline the nitrate concentration increased to reach $24.0 \pm 0.1$ and $23.3 \pm 0.5 \mu \mathrm{M}$ below $150 \mathrm{~m}$ during the March and August cruises,
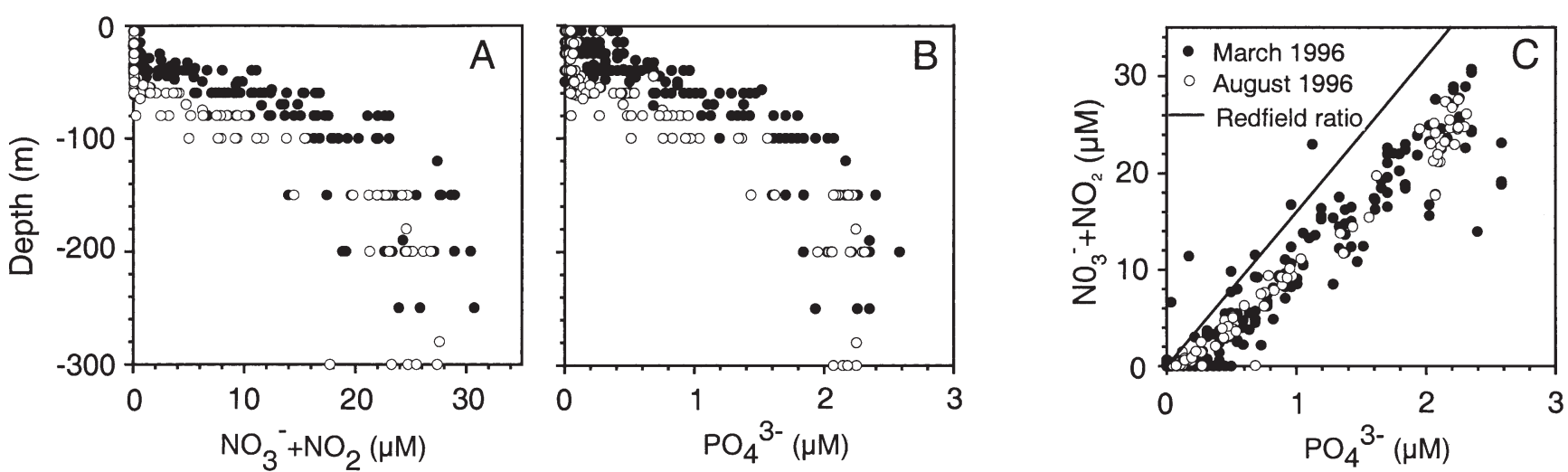

Fig. 6. Vertical distribution of $(A)$ nitrate and nitrite $(\mu \mathrm{M})$, (B) phosphorus $(\mu \mathrm{M})$, and $(\mathrm{C})$ the relationship between nitrate + nitrite and phosphorus in relation to the Redfield ratio (16N:1P) during the 2 seasons 
respectively (Fig. 6A). The vertical distribution of nitrite mirrored that of nitrate. However, nitrite contributed only $<1 \%$ of the nitrate. The vertical distribution of inorganic phosphorus resembled that of nitrate, with low concentrations above the pycnocline (Fig. 6B). In contrast to nitrate, the concentration of inorganic phosphorous was measurable in the surface layer; $0.13 \pm 0.02$ and $0.05 \pm 0.004 \mu \mathrm{M}$ during the March and August cruises, respectively. Across the pycnocline, the concentration of phosphorus increased to $2.18 \pm 0.05 \mu \mathrm{M}$ (March) and $1.79 \pm 0.13 \mu \mathrm{M}$ (August) at $150 \mathrm{~m}$ depth. The ratio of nitrogen to phosphorous based on all measurements was $11.28, r^{2}=0.92$ (March) and 11.25, $\mathrm{r}^{2}=0.98$ (August) (Fig. 6C). If considering only samples below the euphotic zone $(>100 \mathrm{~m})$, the derivation from the Redfield ratio (N/P = 16) is even more pronounced.

\section{Phytoplankton biomass and composition}

In the upper nitrogen-depleted surface layer of the water column, the chl a concentration was very low, typically in the range of 0.05 to $0.1 \mu \mathrm{g} \mathrm{chl} \mathrm{a} \mathrm{l}^{-1}$ in both seasons. In association with the increasing nutrient concentrations in the pycnocline, a positive response in the chl a concentrations was observed (Fig. 4). The overall distribution of the chl a fluorescence thus largely followed the stratification of the water column, with highest values measured in the pycnocline, where concen-

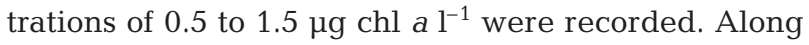
each transect the highest chl a concentration was observed in the front established at mid shelf where the pycnocline meets the bottom (Fig. 4). Here salt nutrient-rich water is introduced to the nutrient-depleted surface layers, fertilising the phytoplankton (Fig. 7) illustrated by the significant and positive correlation between the salinity and the chl a concentration in $10 \mathrm{~m}$ (ANOVA, $\mathrm{n}=56, \mathrm{p}<0.01$ ). In most cases, the highest chl a concentration was observed in association with these fronts. In spite of the very large internal waves at the lower shelf slope (Figs. 2 \& 3), no indication of an introduction of nutrients to the nitrogen-depleted surface layer was apparent in this otherwise very dynamic hydrographic zone. No statistically significant differences regarding the plankton were observed between the transects. Following the deepening of the pycnocline from March to August, the depth of the chl a peak also shifted from 30-40 $\mathrm{m}$ to 60-70 $\mathrm{m}$ depth.

In both seasons the integrated $\mathrm{chl} \mathrm{\textrm {m } ^ { - 2 }}$ showed pronounced station-to-station variation along the transects. However, there was a tendency of increased val-

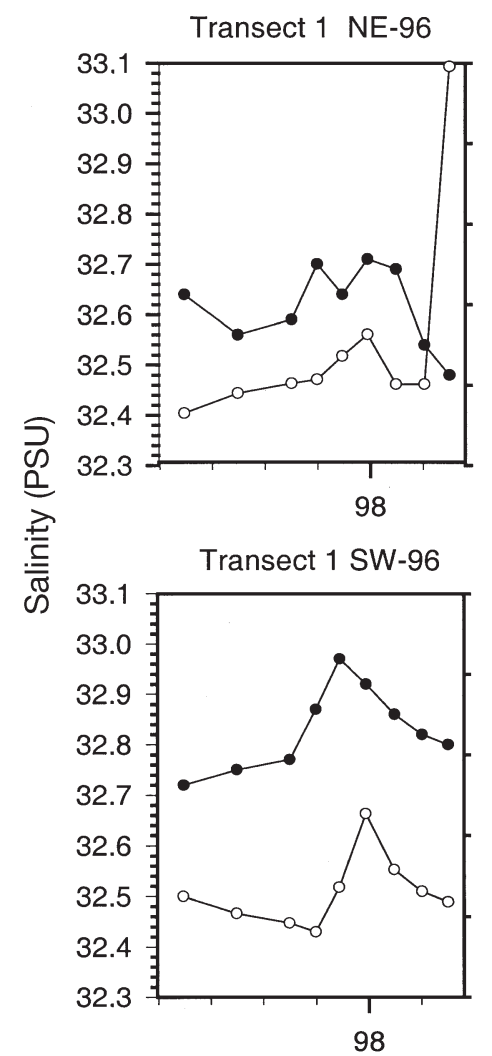

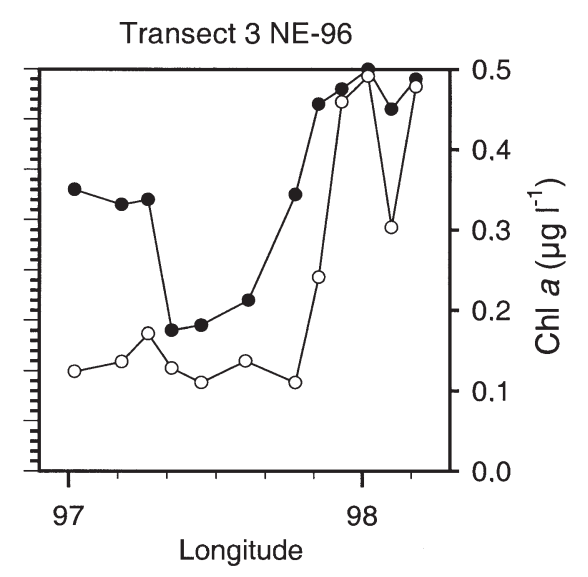

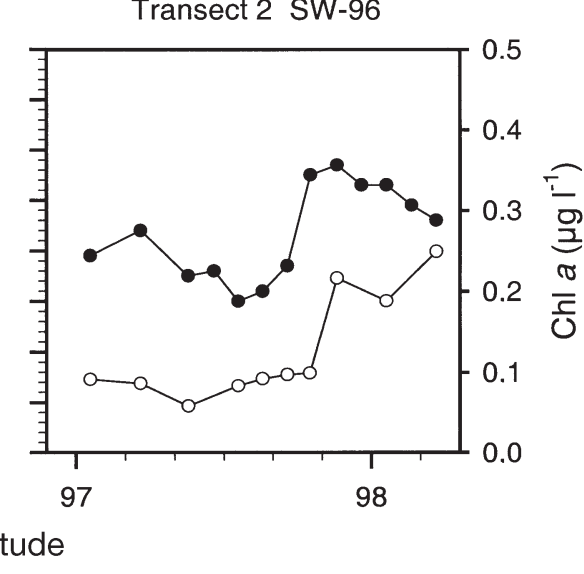

Fig. 7. Salinity (PSU) (०-० corresponds

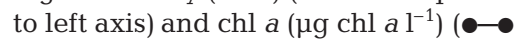
corresponds to right axis) at $10 \mathrm{~m}$ depth along each transect during the March and August cruises 
ues in association with the mid- shelf front (Fig. 8A,B). This trend was corroborated by the depth distribution of integrated phytoplankton, calculated from the samples analysed by microscopy (Fig. 8C,D)

No seasonal or horizontal differences in the integrated biomass or species composition of the phytoplankton community were observed. On both cruises, the picophytoplankton dominated the phytoplankton community (Fig. 8E,F), especially Synecochococcus, which was very abundant contributing $72 \pm 4$ and $74 \pm 4 \%$ of the integrated autotrophic biomass in March and August, respectively. Autotrophic flagellates, especially autotrophic gymnodinoid dinoflagellates and haptophytes, were less important, with a contribution of $5 \pm 1$ and $15 \pm 3 \%$ of the integrated biomass during March and August, respectively. The net plankton fraction, i.e. $>20 \mu \mathrm{m}$, comprised diatoms and autotrophic dinoflagellates, with diatoms (Pseudonitzchia, Thalassionema, Cylindrotheca and Pleurosigma) contributing $23 \pm 4$ and $11 \pm 2 \%$ of the integrated phytoplankton community in March and August, respectively. In addition, the filamentous cyanobacterium genus Trichodesmium was observed, both in near-shore waters and offshore. There was a relatively good correspondence between the integrated chl $a$ and carbon biomasses estimated from microscopy $\left(\mathrm{r}^{2}=0.5, \mathrm{n}=21\right)$. The average conversion factor from chl a to carbon was $42 \pm 10$. If the surface and the depth of maximum chl $a$ is considered separately, conversion factors of 74 and 35 are obtained for the surface and pycnocline population, respectively. The photoacclimatisation illustrated by the ratio of the conversion factors, 2.2, is similar to the ratio obtained from the combustion of the CHN filters, $2.8 \pm 0.6, \mathrm{n}=15$.

The integrated primary production showed pronounced variation along the transects. During both cruises, a peak in primary production, ca. $1500 \mathrm{mg} \mathrm{C}$ $\mathrm{d}^{-1}$, was observed in association with the midshelf front (Fig. 8G,H). There was no significant difference in the primary production between the 3 zones or the 2 seasons; the average integrated primary production was $684 \pm 79, \mathrm{n}=19$ and $569 \pm 76, \mathrm{n}=16 \mathrm{mg} \mathrm{C} \mathrm{m}^{-2} \mathrm{~d}^{-1}$ during the March and August cruises, respectively.
$\mathrm{NE}-96$
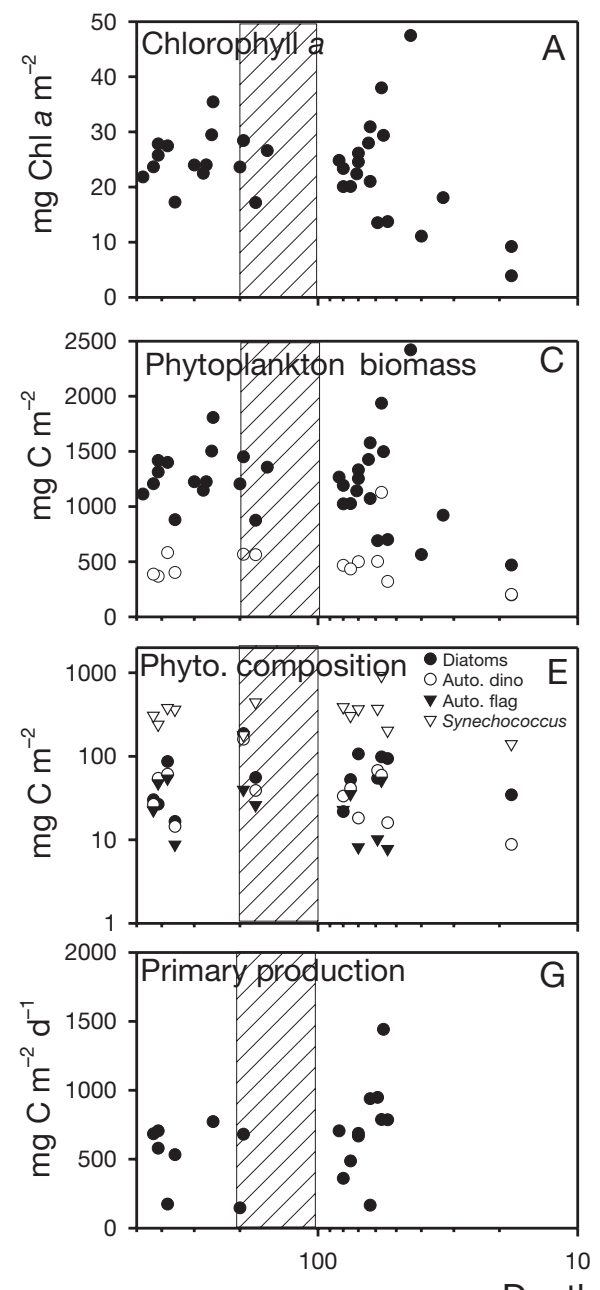

Depth $(m)$
SW-96
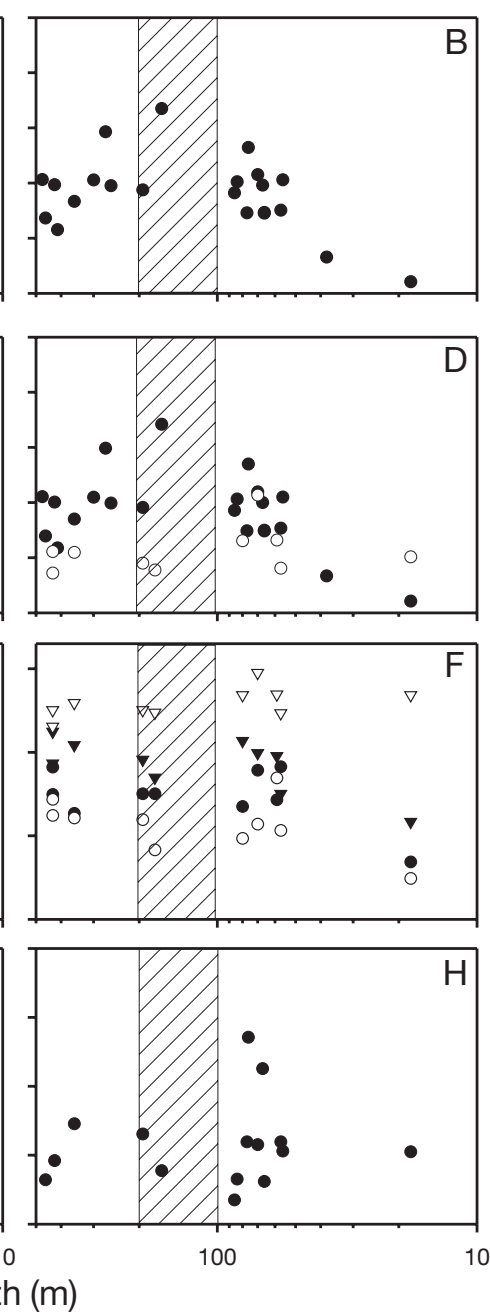

Fig. 8. Integrated phytoplankton biomass $\left(\mathrm{m}^{-2}\right)$ expressed as $(\mathrm{A}, \mathrm{B}) \mathrm{chl}$ a $(\mathrm{mg}$ files along the transects $(\bullet)$. $(\mathrm{E}, \mathrm{F})$ Contribution of dominating phytoplankton groups (note log scale), and (GH) integrated primary production $\left(\mathrm{mgC} \mathrm{m}^{-2} \mathrm{~d}^{-1}\right)$ for the 2 seasons. Shading indicates the upper shelf slope

Bacterioplankton

Bacterial abundance varied between 2 and $2.6 \times$ $10^{5}$ cells $\mathrm{ml}^{-1}$ (Table 1 ). No significant differences were observed in abundance data between the cruises or amongst the 3 depth strata sampled (Table 1). The average bacterial biomass was $652 \pm$ 65 and $867 \pm 72 \mathrm{mgC} \mathrm{m}^{-2}$ during the $\mathrm{NE}$ and SW cruise, respectively (Fig. 9A,B). The integrated bacterial production showed no systematic variation along the transect; the average integrated bacterial production was $139 \pm 13, \mathrm{n}=16$ and $140 \pm 37, \mathrm{n}=7 \mathrm{mgC}$ $\mathrm{m}^{-2} \mathrm{~d}^{-1}$ during March and August, respectively (Fig. 9C,D). 
NE-96

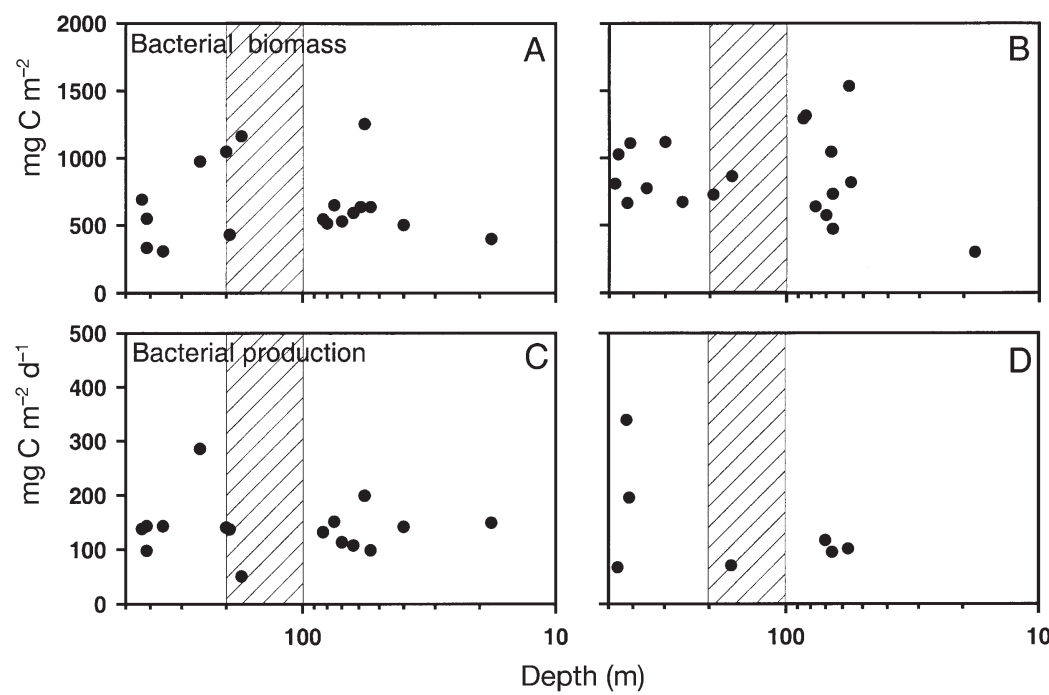

Fig. 9. $(\mathrm{A}, \mathrm{B})$ Integrated bacterial biomass $\left(\mathrm{mg} \mathrm{C}^{-2}\right)$ and $(\mathrm{C}, \mathrm{D})$ bacterial production $\left(\mathrm{mg} \mathrm{C} \mathrm{m}^{-2} \mathrm{~d}^{-1}\right.$ ) for the 2 seasons. Shading indicates the upper shelf slope

Table 1. Bacterial abundance $\left(10^{5}\right.$ cells $\mathrm{ml}^{-1}$; mean $\left.\pm \mathrm{SE}\right)$ and average cell volume $\left(\mu \mathrm{m}^{3}\right.$; mean $\left.\pm \mathrm{SE}\right)$ in the 3 depth strata sampled during cruises NE-96 and SW-96

\begin{tabular}{|c|c|c|c|c|}
\hline & \multicolumn{2}{|c|}{$\begin{array}{c}\text { Abundance } \\
\left(\times 10^{5} \text { cells ml }^{-1}\right)\end{array}$} & \multicolumn{2}{|c|}{$\begin{array}{c}\text { Cell volume } \\
\left(\mu \mathrm{m}^{3}\right)\end{array}$} \\
\hline & NE-96 & SW-96 & NE-96 & SW-96 \\
\hline Surface (5 m) & $2.13 \pm 0.36$ & $2.31 \pm 0.23$ & $0.12 \pm 0.02$ & $0.15 \pm 0.02$ \\
\hline $\begin{array}{l}\text { Depth of max. } \\
\text { fluorescence }\end{array}$ & $2.58 \pm 0.34$ & $2.43 \pm 0.30$ & $0.16 \pm 0.04$ & $0.15 \pm 0.02$ \\
\hline Above bottom or $100 \mathrm{~m}$ & $1.98 \pm 0.24$ & $2.23 \pm 0.19$ & $0.14 \pm 0.02$ & $0.17 \pm 0.01$ \\
\hline
\end{tabular}

Heterotrophic nanoflagellates

The abundance of heterotrophic nanoflagellates varied between 1 and $5 \times 10^{2}$ cell $\mathrm{ml}^{-1}$. The heterotrophic nanoplankton community was dominated by miscellaneous heterotrophic flagellates, loricate choanoflagellates and dinoflagellates, listed in decreasing order of importance in Table 2. Athecate dinoflagellates in the 10 to $20 \mu \mathrm{m}$ size category dominated the heterotrophic assemblage. Additionally the 'incertae sedis' genus Leucocryptos was a noticeable component of this size class, but occurred only in low numbers. In the size category 2 to $5 \mu \mathrm{m}$, miscellaneous heterotrophic flagellates with unknown taxonomic affinity were dominant and loricate choanoflagellates, such as species belonging to the genera Cosmoeca, Platypleura and Stephanacantha, were present as well. In general, the highest abundance was observed in the euphotic zone. There was considerable cross-shelf variation within each cruise. However, no major seasonal difference was observed in abundance data. The average integrated biomass of heterotrophic nanoflagellates was $29 \pm 7$ and $28 \pm 3 \mathrm{mg} \mathrm{C}$ $\mathrm{m}^{-2}$ during the March and August cruises, respectively (Fig. 10A,B).

Table 2. Heterotrophic nanoflagellate abundance (cells $\mathrm{ml}^{-1}$; mean $\pm \mathrm{SE}$ ) and cell volume $\left({\mu \mathrm{m}^{3}}^{3}\right.$; mean $\left.\pm \mathrm{SE}\right)$ in the 3 depth strata sampled during cruises NE-96 and SW-96

\begin{tabular}{|c|c|c|c|c|}
\hline & \multicolumn{2}{|c|}{ Abundance $\left(\times 10{\left.\text { cells } \mathrm{ml}^{-1}\right)}^{-1}\right.$} & \multicolumn{2}{|c|}{ Cell volume $\left(\mu \mathrm{m}^{3}\right)$} \\
\hline & NE-96 & SW-96 & NE-96 & SW-96 \\
\hline \multicolumn{5}{|l|}{ Surface (5 m) } \\
\hline Heterotrophic dinoflagellates & $9.7 \pm 6.8$ & $8.5 \pm 8.3$ & $64 \pm 9.4$ & $73 \pm 8$ \\
\hline Choanoflagellates & $11.0 \pm 6.8$ & $12.0 \pm 1.7$ & $12 \pm 1.6$ & $14 \pm 3$ \\
\hline Leucocryptos sp. & $0.1 \pm 0.4$ & $0.5 \pm 0.4$ & $124 \pm 36$ & 40 \\
\hline Miscellaneous & $280 \pm 99$ & $220 \pm 73$ & $7 \pm 1$ & $11 \pm 2$ \\
\hline Total & $301 \pm 100$ & $241 \pm 86$ & $31 \pm 6$ & $29 \pm 6$ \\
\hline \multicolumn{5}{|l|}{ Depth of max. fluorescence } \\
\hline Heterotrophic dinoflagellates & $13.0 \pm 6.6$ & $9.0 \pm 1.0$ & $52 \pm 5$ & $69 \pm 29$ \\
\hline Choanoflagellates & $19.0 \pm 2.9$ & $11.0 \pm 2.3$ & $12 \pm 1$ & $11 \pm 2$ \\
\hline Leucocryptos sp. & $0.6 \pm 1.7$ & $0.5 \pm 1.6$ & $69 \pm 5$ & $63 \pm 1$ \\
\hline Miscellaneous & $270 \pm 100$ & $250 \pm 130$ & $8 \pm 1$ & $8 \pm 1$ \\
\hline Total & $303 \pm 120$ & $271 \pm 140$ & $26 \pm 3$ & $29 \pm 9$ \\
\hline \multicolumn{5}{|l|}{ Above bottom or $100 \mathrm{~m}$} \\
\hline Heterotrophic dinoflagellates & $5.6 \pm 4.9$ & $3.4 \pm 3.3$ & $47 \pm 15$ & $43 \pm 10$ \\
\hline Choanoflagellates & $7.2 \pm 9.2$ & $6.4 \pm 2.4$ & $12 \pm 4$ & $7 \pm 1$ \\
\hline Miscellaneous & $140 \pm 68$ & $250 \pm 65$ & $4 \pm 1$ & $6 \pm 1$ \\
\hline Total & $153 \pm 73$ & $260 \pm 64$ & $19 \pm 6$ & $17 \pm 6$ \\
\hline
\end{tabular}


Microprotozooplankton

The microprotozooplankton was dominated by heterotrophic dinoflagellates and ciliates (Fig. 10C-F. Dinoflagellates contributed more than $50 \%$ of the microprotozooplankton biomass during March, while both groups contributed equal shares to the integrated microprotozooplankton biomass during August. Despite the pronounced phytoplankton subsurface peak, the protozoan biomass and abundance was the same in the surface and subsurface chl a peak at the pycnocline (Table 3). The average biomass was 0.5 to $1 \mu \mathrm{g}$ $\mathrm{C} \mathrm{I}^{-1}$, where the highest biomasses were observed nearshore at the shelf break. The dinoflagellate community was dominated by naked forms e.g. Gyrodinium spirale, G. dominans, G. glaucum, Cochlodinium sp. and a mixotrophic Torodinium sp. Only few Protoperidinium spp. and Dinophysoid species were observed. The average integrated biomass of heterotrophic dinoflagellates was $38 \pm$ 2 and $33 \pm 4 \mathrm{mg} \mathrm{C} \mathrm{m}^{-2}$ during the March and August cruises, respectively. Naked oligotrichs (Strombidium spp., Strobilidium spp., Tontonia and Legardiella sol) dominated ciliate biomass. Tintinnids and Mesodinium rubrum were also observed, but in very low numbers. The average integrated ciliate biomass was $31 \pm 3$ and $45.3 \pm 3 \mathrm{mg} \mathrm{C} \mathrm{m}^{-2}$ during the March and August cruises, respectively. For further details see P. J. Hansen \& T. G. Nielsen (unpubl.).

\section{DISCUSSION}

\section{Internal waves}

The Andaman Sea is known as the site of the world's largest soliton (Osborne \& Burch 1986). The internal waves are generated at the Nicobar Islands at the eastern border of the Andaman Sea, and tidal movements

Table 3. Abundance of ciliates and heterotrophic dinoflagellates $>20 \mu \mathrm{m}$ (cells $\mathrm{ml}^{-1} \pm \mathrm{SE}$ ) in the 3 depth strata sampled during cruises NE-96 and SW-96

\begin{tabular}{|lccccc|}
\hline & \multicolumn{2}{c}{ Ciliates } & HE-96 & & \multicolumn{2}{c|}{ SW-96 } \\
\cline { 2 - 3 } \cline { 5 - 6 } & $0.63 \pm 0.08$ & $0.61 \pm 0.08$ & & $1.00 \pm 0.05$ & $1.74 \pm 0.07$ \\
\hline $\begin{array}{c}\text { Surface }(5 \mathrm{~m}) \\
\begin{array}{c}\text { Depth of max. } \\
\text { fluorescence }\end{array}\end{array}$ & $0.73 \pm 0.07$ & $0.59 \pm 0.06$ & & $1.09 \pm 0.08$ & $1.15 \pm 0.35$ \\
$\begin{array}{c}\text { Above bottom } \\
\text { or 100 m }\end{array}$ & $0.34 \pm 0.09$ & $0.33 \pm 0.09$ & & $0.27 \pm 0.03$ & $0.21 \pm 0.02$ \\
\hline
\end{tabular}

over the shallow inlets between the Islands create the solitons (Osborne 1990). Solitons typically occur in tows comprising about 6 to 8 waves. The waves within a tow are normally rank ordered by amplitude, with the largest in front (Osborne 1990). The interval between each packet is ca. $12.4 \mathrm{~h}$ synchronous with the tidal period of the Andaman Sea (Osborne 1990). During the present investigation, we were not able to deploy adequate equipment, i.e. moored and ship based ADCP's, to resolve the patterns of the waves. However, during Cruise SW-96, temperature loggers were deployed along the transects at the depth of the pycnocline (data not shown). As illustrated by wave height measured in the present study (Fig. 3), oscillations of the pycnocline were primarily observed from the midshelf front (60 $\mathrm{m}$ depth) and further offshore. When the 'original' soliton packet is generated every $12.4 \mathrm{~h}$, the radiation trailing behind the soliton separates into more packets (Osborne 1990). This is in accordance with our observations of a nearly continuous series of pulses off shelf (T. G. Nielsen et al. unpubl. data), with no apparent 
tidal periodicity. Along our transects the highest waves, $>60 \mathrm{~m}$, were observed where the wave packets encounter the shelf break at 250 to $350 \mathrm{~m}$ bottom depth (Fig. 3).

Direct observations of breaking oceanic solitons are rarely documented (Haury et al. 1983). However an amplification of the wave height, as observed in the present study, possibly leads to increased mixing of the water column. The effect of mixing might be observed directly or indirectly. Directly through an increase in surface nutrient concentration or salinity (Holligan et al. 1985) or a temperature reduction (Holligan et al. 1985), or indirectly through enhanced biomass, average cell size or primary or secondary production at the site of mixing (Kiørboe 1993, Nielsen et al. 1993). We do not have direct evidence of solitons breaking at the shelf slope where the amplitude of the wave was largest. However, in the present study an increase in surface salinity was observed, where the waves encounter the shoal water on the shelf slope in association with the mid-shelf front (Fig. 7), illustrating mixing of the sub-pycnocline nutrient-rich water upwards into the surface layer. Increase in the nutrient concentrations could not be detected, but a significant increase in chl a was observed at the shelf slope front. The lack of a nutrient signal was probably due to prompt assimilation of the nutrients by phytoplankton.

\section{Implications of solitons on the pelagic community}

Because of the strong thermal stratification in the Andaman Sea, the primary producers depleted inorganic nitrogen from the surface layer down to the pycnocline at 30 to $40 \mathrm{~m}$ and 60 to $70 \mathrm{~m}$ depth during the NE-96 and SW-96 cruises, respectively (Figs. 4 \& 6). Primary production above the pycnocline is fuelled by regenerated nitrogen from the heterotrophs, and new production will only occur when nutrients from the lower part of the pycnocline are transported to the surface waters through erosion of the pycnoline or from land-based sources. As frequently observed in other stratified waters, accumulation of chl a was observed at the pycnocline, where light is supplied from above and nutrients from below. The subsurface chl a maximum may thus act as a drain of nutrients mixed upwards from below the pycnocline (Pingree et al. 1977), reducing the nutrients available for the surface phytoplankton population.

The internal wave may have major implications for the phytoplankton community by lifting the pycnocline phytoplankton to more favourable average light conditions, and by creating shear and turbulence which cause injections of nutrients to the depleted surface community, especially if waves are amplified or break
(Haury et al. 1983, Lande \& Yentsch 1988). During the passage of a wave (Fig. 2), the light climate of the pycnocline phytoplankton oscillates between $0.3(5 \mu \mathrm{E}$ $\left.\mathrm{m}^{-2} \mathrm{~s}^{-1}\right)$ and $8 \%\left(130 \mu \mathrm{E} \mathrm{m} \mathrm{m}^{-2} \mathrm{~s}^{-1}\right)$ of the surface irradiance. Consequently the pycnocline phytoplankton community is lifted from below the compensation point up to the euphotic zone during passage of a wave tow. Assuming that primary production in the lower euphotic zone is light- rather than nutrient-limited (MacIsaac \& Dugdale 1972), this will clearly increase new primary production in the lower part of the euphotic zone. Calculating the primary production level at the 2 extremes, i.e. when the florescence peak is in the wave crest and trough, results in an integrated primary production of 1140 and $826 \mathrm{mg} \mathrm{C} \mathrm{m}^{-2} \mathrm{~d}^{-1}$, respectively. However because the light conditions at the pycnocline are on the linear part of the PI-curve the irradiance available to the primary producers should be computed as the average light experienced during the passage.

Judged from the $\mathrm{N}: \mathrm{P}$ ratio in the surface water of $3.7 \pm 0.7$ and $1.3 \pm 0.8$ during March and August, respectively, and the vertical availability of nitrate with surface concentrations close to the detection limit, the plankton community was nitrogen depleted during both seasons (Fig. 6). This assumption is supported by experiments conducted in parallel with the present cruises, clearly demonstrating that additions of nutrient to surface-water results in an immediate response in the biomass of phyto- and microprotozooplankton (P. J. Hansen \& T. G. Nielsen unpubl.). The microcosm experiments also illustrate a qualitative change of the phytoplankton from picoplankton towards large diatoms (P. J. Hansen \& T. G. Nielsen unpubl.).

Injection of nutrients to the surface layer due to mixing (Holligan et al. 1985, Pingree et al. 1986) or ultimately breaking of the internal waves (Woods \& Wiley 1972) has been documented from other areas. Such episodic disturbances of the water column are often sites of enhanced plankton production (Legendre 1981). Prior to the present investigation, we assumed that nutrient-rich water mixed into the surface layer at the shelf break (Figs. 2 to 4). However, measurements of primary production and standing stocks of planktonic organisms along the transects did not support the hypothesis of injection of nutrient rich bottom water at the shelf break.

\section{Impact of water column structure on the pelagic community}

A characteristic feature of the Andaman Sea plankton community was the subsurface chlorophyll maximum layer centred around the pycnocline, as observed 
in other stratified waters when nutrients in the surface layer are depleted (Bhattathiri et al. 1996). However, this subsurface chl a peak was, to a large extent, due to increased specific chl a concentration of the subsurface populations rather than a genuine biomass accumulation, illustrated by the 2.2- to 2.6-times lower chl a carbon conversion factor for the pycnocline population compared with the surface. This assumption is corroborated by the vertical distribution of the succeeding heterotrophic links in the food chain, where no differences between surface and pycnocline biomasses were observed for bacteria (Table 1), heterotrophic nanoflagellates (Table 2) or ciliates and dinoflagellates (Table 3). However, despite the lack of a numerical response of the heterotrophic community associated with the subsurface bloom, the turn-over of the populations could be faster than in the water column above.

\section{Productivity of the Andaman Sea}

In tropical marine ecosystems where surface water temperature is constantly high, the thermal stratification of the water column results in strong nutrient limitation of the phytoplankton population (Woodward et al. 1999). The nitrate concentrations and vertical distribution of primary producers measured during the present study are comparable to what is reported from the western Andaman Sea (Gomes et al. 1992) and other tropical oligotrophic waters, e.g. Arabian Sea (de Souza et al. 1996, Woodward et al. 1999) and Banda and Arfura Sea (Wetsteyn et al. 1990). The present study illustrates a pronounced effect of stratification on the primary producers across the shelf and the shelf slope. On the other hand, despite the very dynamic nature of the of the pycnocline and the nutrient depletion of the surface community, it was not possible to identify higher phytoplankton production at the immediate shelf break in the Andaman Sea, as suggested by previous investigators (Wium-Andersen 1977, Yesaki \& Jantarapagdee 1981, Kiørboe et al. 1991). However, enhanced primary production and biomass of phytoplankton was observed further onshore at the mid-shelf front where our observations indicate introduction of cold, salt, nutrient rich water to the upper layers (Figs. 4 \& 7).

Outside the mid-shelf front the integrated primary production was fairly stable, and it was high from the midshelf front and across the shelf slope, $684 \pm 79$ and $569 \pm 76 \mathrm{mg} \mathrm{C} \mathrm{m}^{-2} \mathrm{~d}^{-1}$ during the NE and SW cruises, respectively. The estimated annual primary production of $229 \mathrm{~g} \mathrm{C} \mathrm{m}^{-2} \mathrm{yr}^{-1}$ is lower than previous measurements from Thai coastal waters of $384 \mathrm{~g} \mathrm{C} \mathrm{m}^{-2}$ $\mathrm{yr}^{-1}$ (Sundström et al. 1987) and 300 to $540 \mathrm{~g} \mathrm{C} \mathrm{m}^{-2} \mathrm{yr}^{-1}$ (Janekarn \& Hylleberg 1989). The integrated primary production of the Andaman Sea is within the range reported from other tropical marine areas influenced by monsoonal forcing (Table 4). Sites of higher production primarily occur along the western coast of India during the SW (summer monsoon), because of coastal upwelling (Battathiri et al. 1996). However, no indication of upwelling was evident during the present investigation.

\section{Seasonal variability of the primary producers and the microbial food web}

Investigations in the Arabian Sea have documented a significantly higher primary production during the NE monsoon (Bhattathiri et al. 1996, Madhupratap et al. 1996, Barber et al. 2001) than during the SE monsoon. The high production observed along the Indian coast during the SE monson is due to a combination of coastal upwelling and airborne iron fertilization of the surface water (Smith 2001). However, despite significant seasonal variation in primary production (Bhattathiri et al. 1996), a similar seasonal pattern could not be documented for bacterial abundance or production (Ramaiah et al. 1996) or microzooplankton biomass (Gauns et al. 1996); the highest heterotrophic activity was observed in the inter-monsoon season. In the Andaman Sea, no quantitative or qualitative difference was observed between the phytoplankton community structure, primary production and the microbial food web during the 2 seasons. The only obvious difference between the 2 seasons was vertical displacement of the nitracline from March to August as also observed in, e.g. the central Arabian Sea (Bhattathiri et al. 1996).

Table 4. Primary production $\left(\mathrm{mgC} \mathrm{m}^{-2} \mathrm{~d}^{-1}\right)$ in the Andaman Sea and other tropical ecosystems influenced by monsoonal forcing. For the present study, means $\pm \mathrm{SE}$ are shown

\begin{tabular}{|lcccc|}
\hline Area & $\begin{array}{c}\text { Dry } \\
\text { NE }\end{array}$ & $\begin{array}{c}\text { Wet } \\
\text { SW }\end{array}$ & Annual & Source \\
\hline $\begin{array}{c}\text { Atlantic Ocean } \\
\text { (Sierra Leone) }\end{array}$ & 450 & 277 & Longhurst (1983) \\
NW Indian Ocean & $500-1000$ & $500-600$ & & Veldhuis et al. (1997) \\
$\begin{array}{c}\text { Arabian Sea } \\
\text { Open ocean }\end{array}$ & $337-643$ & 770 & & Bhattathiri et al. (1996) \\
Coastal & $200-807$ & $440-1760$ & & $\begin{array}{l}\text { Bhattathiri et al. (1996) } \\
\text { Gomes et al. (1992) }\end{array}$ \\
$\begin{array}{c}\text { Andaman Sea, } \\
\text { western side }\end{array}$ & $90-390$ & & & Present study \\
Andaman Sea, & $684 \pm 79$ & $569 \pm 76$ & 229 & \\
eastern side & & & & \\
\hline
\end{tabular}



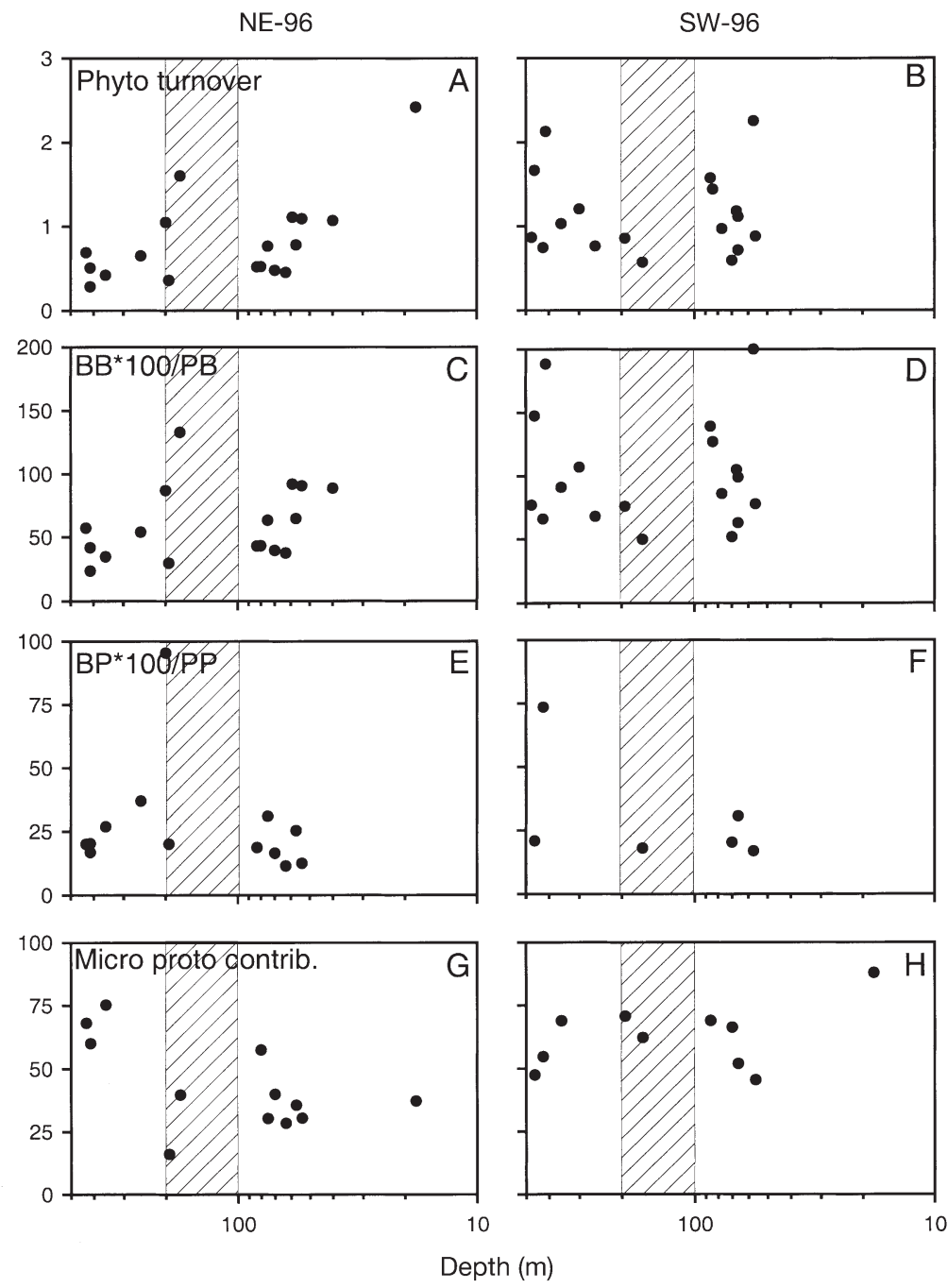

Fig. 11. $(\mathrm{A}, \mathrm{B})$ Turnover of phytoplankton biomass PP:PB d $\mathrm{d}^{-1}$, and $(\mathrm{C}, \mathrm{D})$ relative importance of bacterial carbon $\mathrm{BB} \times 100 / \mathrm{PB}$. $(\mathrm{E}, \mathrm{F})$ Relative importance of bacterial production $\mathrm{BP} \times 100 / \mathrm{PP}$, and $(\mathrm{G}, \mathrm{H})$ relative importance of the microprotozooplankton to the copepod diet (i.e. net phytoplankton + microprotozooplankton along transects for the 2 seasons. PP: primary production; PB: phytoplankton biomass; BP: bacterial production; BB: bacterial biomass. Shading indicates the upper shelf slope

Since the pycnocline prevents the fertilisation of the euphotic zone, our measured primary production is largely relying on regenerated nutrients. However, between the cruises a significant amount of nitrate was introduced to the surface layer, as the pycnocline was eroded $28 \mathrm{~m}$ deeper down (Fig. 6). Assuming a subpycnocline nitrate concentration of $24 \mu \mathrm{M}$, corresponding to $336 \mathrm{mg} \mathrm{N} \mathrm{m}^{-3}$, and a C:N stoichiometric ratio of $6.6: 1$, the introduced nitrate will potentially give rise to a new production of $62 \mathrm{~g} \mathrm{C} \mathrm{m}^{2}$. This is a significant addition to the estimated annual production of $229 \mathrm{~g} \mathrm{C}$ $\mathrm{m}^{-2} \mathrm{yr}^{-1}$. This is not a gradual process, but rather is associated with the increase in wind energy in May and
June (Janekarn et al. 2001). Such a sudden addition of nutrients will presumably give rise episodic blooms of large cells implicating the structure and function of the pelagic food web, as illustrated by our microcosm experiments (P. J. Hansen \& T. G. Nielsen unpubl.).

\section{The Andaman Sea food web compared with other systems}

So far most of the investigations on the microbial ecology of tropical seas have been conducted in the Pacific (Chavez et al. 1996) and Atlantic Oceans (Buck et al. 1996, Zubkov et al. 1998) and the Arabian Sea (Ramaiah et al. 1996, Brown et al. 1999, Garrison et al. 2000). The eastern side of the Indian Ocean and the Andaman Sea have received much less attention. However, the structure and complexity of the Andaman Sea pelagic food web, resembles that described from other oligotrophic subtropical and tropical ecosystems (Sorokin et al. 1985, Buck et al. 1996, Veldhuis et al. 1997 , Garison et al. 2000, Siokou-Frangou et al. 2002). The most important feature of these systems is the significance of the picophytoplankton fraction. The small size of the primary producers (Fig. 8E,F) and the significant contribution of bacterial biomass (Fig. 11C,D) and production (Fig. 11E,F) to the pelagic food web illustrates the key role of the microbial food web in transferring the primary production up the food web (Fig. 12). The dominating protist grazers, i.e. the heterotrophic nanoflagellates and small oligotrich ciliates, in contrast to the copepods, have the potential to exploit these carbon sources directly (Christaki et al. 1998, 2002). The other key groups of microproto-zooplankton, the heterotrophic dinoflagellates, belong to the same size class as the ciliates, but from a functional point of view they act differently. Ciliates mainly predate on prey $\sim 1: 10$ of their cell volume while dinoflagellates may have a 1:1 predator:prey ratio (Hansen et al. 1994). The Andaman Sea dinoflagellates must consequently to a large degree rely on the ciliates that dominate their potential food source (Figs. 11G,H \& 12). The relatively high biomass of microprotozooplankton compared with the larger phytoplankton fraction (Fig. 11G,H) indicates a very strong coupling between the copepods and the microbial food web as documented by Satapoomin et al. (2004). Compared 
with tropical upwelling areas where relatively large phytoplankton cells are directly available to the copepods, the Andaman Sea pelagic food web is relatively complex, with 4 to 5 trophic levels and a significant respiratory loss before the small primary producers enter the classical food web (Fig. 12). The only mesozooplankton able to shortcut the food web, the appendicularians, by exploiting the picoplankton directly were not sampled quantitatively and thus not included in the budget. However, based on our semi quantitative data
(Munk et al. 2004), the appendicularians potentially are an important element of the Andaman Sea, which should be considered in future studies.

\section{CONCLUSION}

The shelf area of the Andaman Sea has the potential of being a productivity 'hotspot', i.e. a persistent front where stratified water meets the mixed coastal

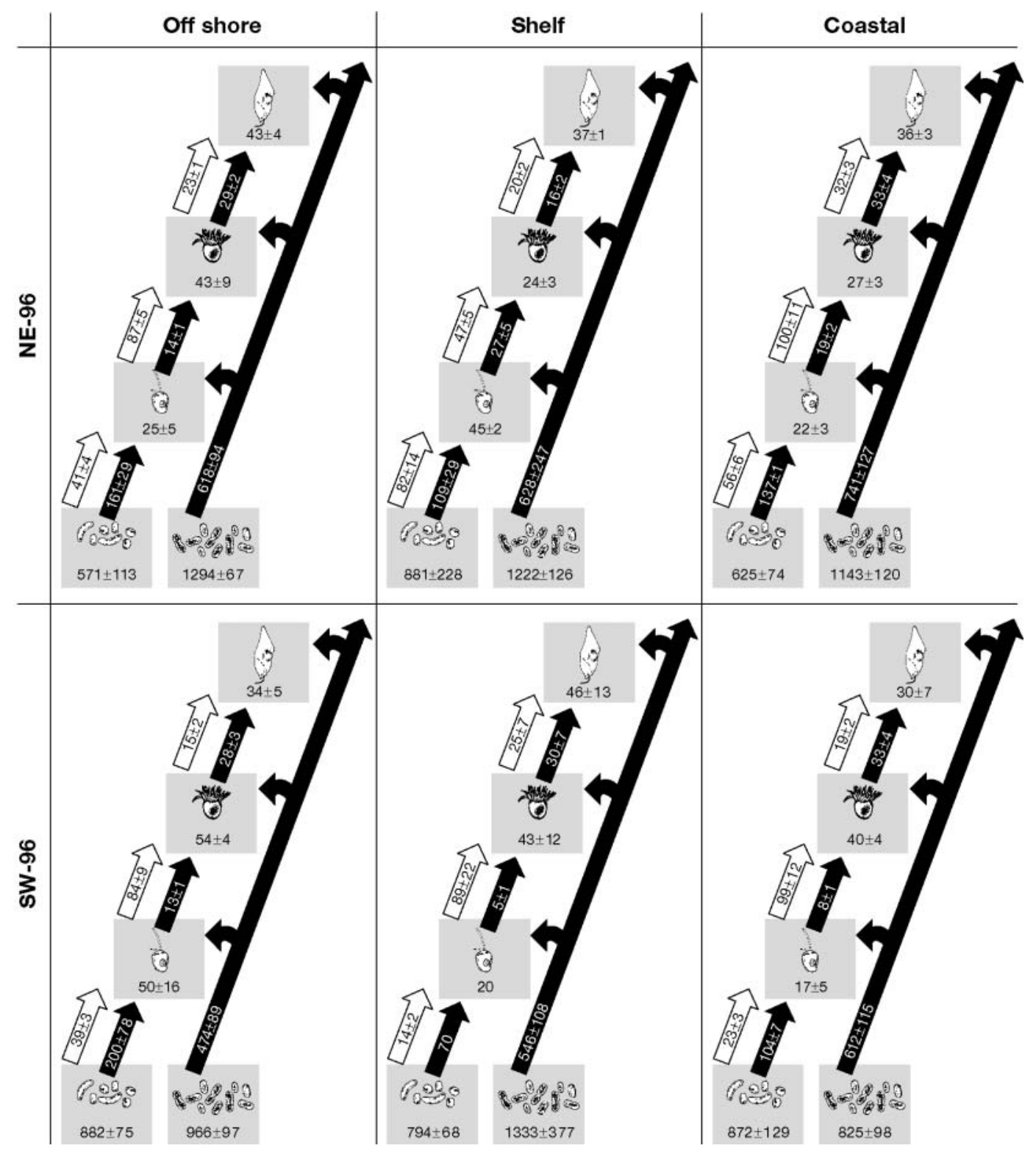

Fig. 12. Carbon budgets of the coastal, shelf and off-shore regions during the 2 seasons. Numbers in the boxes illustrate biomass $\left(\mathrm{mg} \mathrm{C} \mathrm{m}{ }^{-2}\right.$ ) and the white arrow entering and black arrow leaving the box illustrate ingestion and production of that particular compartment of the microbial food web $\left(\mathrm{mg} \mathrm{C} \mathrm{m}^{-2} \mathrm{~d}^{-1}\right)$. Potential ingestion of the protists was calculated from the average volume

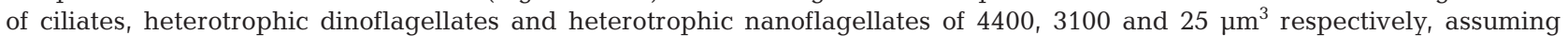
maximum clearance and a $Q_{10}$ of 2.8 (Hansen et al. 1997) 
water in combination with a very dynamic oceanography. Previous investigations in the Andaman Sea (Wium-Andersen 1977, Yesaki \& Jantarapagdee 1981, Kiørboe et al. 1991) have suggested that a shelf-break front was highly productive and potentially important for the productivity of the area. However, regardless of high spatial resolution across of the very dynamic shelf, no peak in primary production or standing stock of key components of the microbial food web was observed. A similar conclusion was reached by Satapoomin et al. (2004) for copepod biomass and egg production rate. One possible explanation is that the strong stratification of the water column prevents the breakage of the internal wave; consequently only small pulses of nitrate are transported upwards and immediately transferred up the fast growing microbial food web. The site of particularly high production was at the mid shelf front where breaking of the shoaling waves persistently introduced cold, salt nutrient-rich water to the euphotic zone, resulting in enhanced phytoplankton biomass and production. Future investigations have to consider this discontinuity carefully if the productivity of this dynamic area is to be thoroughly understood.

Acknowledgements. We are to the grateful staff of the Marine Biological Productivity Unit. PMBC for support and the crew of RV 'Chrakratong Tongyai' for their assistance during field work. T. Kiørboe is thanked for his constructive comments to the manuscript. This work is supported by The Department of Fisheries (Thailand), DANIDA Grant \#104.P.3 Thailand to S.S., the Danish National Research Council Grant \#9801391 to T.G.N. and P.J.H. and a PhD grant to J.B.Ø. funded by the Faculty of Science, University of Copenhagen. This is contribution \#48 of the PMBC.

\section{LITERATURE CITED}

Barber RT, Marra J, Bidigare RC, Codispoti LA and 5 others (2001) Primary productivity and its regulation in the Arabian Sea during 1995. Deep-Sea Res Part II 48:1127-1172

Bhattathiri PMA, Pant A, Sawant S, Gauns M, Matondkar SGP, Mahanraju R (1996) Phytoplankton production and chlorophyll distribution in the eastern and central Arabian Sea in 1994-1995. Curr Sci 71:857-862

Boonruang P (1985) The community structure, abundance and distribution of zooplankton at the eastcoast of Puket Island, southern Thailand, Andaman Sea. Phuket Mar Biol Res Bull 39:1-13

Brown SL, Landry MR, Barber RT, Campbell L, Garrison DL, Gowing MM (1999) Picophytoplankton and production in the Arabian Sea during the 1995 southwest monsoon, Deep-Sea Res II 46:1745-1768

Buck KR, Chavez FP, Campell L (1996) Basin-wide distribution of living carbon components and the inverted trophic pyramid of the central gyre of the North Atlantic Ocean summer 1993. Aquat Microb Ecol 10:283-298

Burkill PH (1999) ARABESQUE: an overview. Deep-Sea Res II 46:529-547
Calbet A, Landry MR (1999) Mesozooplankton influences on the microbial food web: direct and indirect trophic interactions in the oligotrophic open ocean. Limnol Oceanogr 44:1370-1380

Campbell L, Nolla HA, Vaulotd D (1994) The importance of Prochlorococcus to community structure in the Central North Pacific Ocean. Limnol Oceanogr 39:954-961

Chavez FP, Buck KR, Service SK, Newton J, Barber RT (1996) Phytoplankton variability in the central and eastern tropical Pacific. Deep-Sea Res II 43:835-870

Christaki U, Dolan JR, Pelegri S, Rassoulzadegan F (1998) Consumption of picoplankton-size particles by marine ciliates: effects of physiological state of the ciliate and particle quality. Limnol Oceanogr 43:458-464

Christaki U, Courties C, Karayanni H, Giannakourou A, Maravelias C, Kormas KA, Lebaron P (2002) Dynamic characteristics of Prochlorococcus and Synechococcus consumption by bacterivorous nanoflagellates. Microb Ecol 43: $341-352$

de Sousa SN, Dileep Kumar M, Sardessai SD, Sarma VVSS, Shirodkar PV (1996) Seasonal variability in oxygen and nutrients in the central and eastern Arabian Sea. Curr Sci 71:847-851

Edler L (1979) Recommendations on methods for marine biological studies in the Baltic Sea-phytoplankton and chlorophyll. Baltic Mar Biol Publ 5:1-35

Eppley RW, Reid FMH, Strickland JDH (1970) Estimates of phytoplankton crop size, growth rates and primary production. Bull Scripps Inst Oceanogr 17:33-42

Fuhrman J, Azam F (1980) Bacterioplankton secondary production estimates for coastal waters of British Colombia, Antarctica and California. Appl Environ Microbiol 39: 1085-1095

Garrison DL, Gowing MM, Hughes MP (1998) Nano- and microplankton in the northern Arabian Sea during the Southeast monsoon, August-September 1995. A USJGOFS Study. Deep-Sea Res 45:2269-2299

Garrison DL, Gowing MM, Hughes MP, Campbell L and 11 others (2000) Microbial food web structure in the Arabian Sea: a US JGOFS study. Deep-Sea Res II 47:1387-1422

Gauns M, Mohanraju R, Madhupratap M (1996) Studies on the microzooplankton from the central and eastern Arabian Sea. Curr Sci 71:874-877

Gedde AD (1996) Floristisk undersøgelse af kiselalger tilhørende underklasserne Coscinodiscophycidae og Thalassiosirophycidae indsamlet i farvandet ud for Phuket (Thailand) - et stadium baseret på lys- og elektronmikroskopiske observationer. MSc thesis, University of Copenhagen

Gedde AD (1999) Thalassiosira andamanica sp.nov. (Bacillariophyceae). A new diatom from the Andaman Sea (Thailand). J Phycol 35:198-205

Gomes HRD, Goes JI, Parulekar AH (1992) Size-fractionated biomass, photosynthesis and dark $\mathrm{CO}_{2}$ fixation in a tropical marine environment. J Plankton Res 14:1307-1329

Haas LW (1982) Improved epifluorescence microscopy for observing planktonic microorganisms. Ann Inst Oceanogr 58:261-266

Hansen B, Bjørnsen PK, Hansen PJ (1994) Prey size selection in planktonic zooplankton. Limnol Oceanogr 39:395-403

Hansen PJ, Bjørnsen PK Hansen B (1997) Zooplankton grazing and growth: scaling within the $2-2000 \mu \mathrm{m}$ body size range. Limnol Oceanogr 42:687-704

Haury LR, Wiebe PH, Orr MH, Briscoe MG (1983) Tidally generated high-frequency internal wave packets and their effects on plankton in Massachusetts Bay. J Mar Res 41:65-112 
Hobbie JE, Daley RJ, Jaspers S (1977) Use of nuclepore filters for counting bacteria by epiflourescence. Appl Environ Microbiol 33:1255-1228

Holligan PM, Pingree RD, Mardell GT (1985) Oceanic solitons, nutrient pulses and phytoplankton growth. Nature 314:348-350

Janekarn V, Hylleberg J (1989) Coastal and offshore primary production along the west coast of Thailand (Andaman Sea) with notes on physical-chemical variables. Phuket Mar Biol Cent Res Bull 51:1-20

Janekarn V, Kiørboe T (1991) The distribution of fish larvae along the Andaman Coast of Thailand. Phuket Mar Biol Cent Res Bull 51:41-61

Janekarn V, Sawangareeruks S, Limtraluvong V, Satapoomin S, Chanasaklniyom S, Mokaratana P, Pornchai K (2001) Resent fisheries discoveries in the Andaman shelf Sea: indirect biological evidence. Proceedings of the annual seminar. Department of Fisheries (in Thai)

Jeffrey SW, Humphrey GF (1975) New spectro-photometric equations for determining chlorophylls $a, b, c_{1}$ and $c_{2}$ in higher plants, algae and natural phytoplankton. Biochem Physiol Pflanzen 167:194-204

Kidwai S, Amjad S (2000) Zooplankton: pre-southwest and northeast monsoons of 1993 to 1994, from the North Arabian Sea. Mar Biol 136:561-571

Kiørboe T (1993) Turbulence, phytoplankton cell size, and the structure of the pelagic food webs. Adv Mar Biol 29:1-73

Kiørboe T, Janekarn V, Poung-in S, Sawangareeruks S, Piukhao P (1991) New fisheries resources in the Andaman Shelf Sea? Indirect oceanographical evidence. Thai Fish Gaz 44:261-270

Krishnaswami S, Nair RR (1996) JGOFS (India). Curr Sci 71: 831-833

Lande R, Yentsch CS (1988) Internal waves, primary production and the compensation depth of phytoplankton. J Plankton Res 10:565-571

Legendre L (1981) Hydrodynamic control of marine phytoplankton production: the paradox of stability. In: Nihoul JCJ (ed) Marine interfaces ecohydrodynamics. Elsevier, Amsterdam, p 1-29

Longhurst AR, Pauly D (1987) Ecology of tropical oceans. Academic Press, San Diego, CA

MacIsaac JJ, Dugdale RC (1972) Interactions of light and inorganic nitrogen in controling nitrogen uptake in the Sea. Deep-Sea Res 25:771-793

Madhupratap M, Kumar SP, Bhattathiri PMA, Kumar MD, Raghukumar S, Nair KKC, Ramaiah N (1996) Mechanism of the biological response to winter cooling in the northeastern Arabian Sea. Nature 384:549-552

Munk P, Bjørnsen PK, Boonruang P, Fryd M and 9 others (2004) Assemblages of fish larvae and meso-zooplankton across the continental shelf and shelf slope of the Andaman Sea (NE Indian Ocean). Mar Ecol Prog Ser 274:87-97

Nielsen TG, Løkkegård B, Richardson K, Pedersen FB, Hansen L (1993), The structure of the plankton communities in the Dogger Bank area (North Sea) during a stratified situation. Mar Ecol Prog Ser 95:115-131

Osborne AR (1990) The generation of internal solitons in the Andaman Sea. In: Fordy AP (ed) Soliton theory: a survey of results. Manchester University Press, Manchester and New York

Osborne AR, Burch TI (1986) Internal solitons in the Andaman Sea. Science 208:451-460

Pingree RD, Holligan PM, Head RN (1977) Survival of dinoflagellate blooms in the western English Channel. Nature 265:266-269
Pingree RD Mardell GT, New AL (1986) Propagation of internal tides from the upper slopes of the Bay of Biscay. Nature 321:154-158

Ramaiah N. Raghukumar S, Gauns M (1996) Bacterial abundance and production in the central and eastern Arabian Sea. Curr Sci 71:878-882

Riemann B, Bjørnsen PK, Newell S, Fallon R (1987) Calculation of cell production of coastal marine bacteria based on measured incoporation of ${ }^{3} \mathrm{H}$-thymidine. Limnol Oceanogr $32: 471-476$

Satapoomin S (1999) Zooplankton communities in the Kapur mangrove canal, Ranong Province, Andaman Sea. Phuket Mar Biol Cent Res Bull 62:33-56

Satapoomin S, Pornchai K (2002) Zooplankton communities in Sapam Bay. Phuket Mar Biol Cent Res Bull 64:53-63

Satapoomin S, Nielsen TG, Hansen PJ (2004) Andaman Sea copepods: spatio-temporal variations in biomass and production, and role in the pelagic food web. Mar Ecol Prog Ser 274:99-122

Simon M, Azam F (1989) Protein content and protein synthesis rates of planktonic marine bacteria. Mar Ecol Prog Ser 51:201-213

Simpson J (1981) The shelf-sea fronts: implication of their existence and behaviour. Phil Trans R Soc Lond 302: 531-546

Siokou-Frangou I, Bianchi M, Christaki U, Christou ED and 9 others (2002) Carbon flow in the planktonic food web along a gradient of oligotrophy in Aegean Sea (Mediterranean Sea). J Mar Syst 33:335-353

Smith SL (2001) Understanding the Arabian Sea: reflections on the 1994-1996 Arabian Sea Expeditions. Deep-Sea Res II 48:1385-1402

Smith S, Roman M, Prusova I, Wishner K and 5 others (1998) Seasonal response of zooplankton to monsoonal reversals in the Arabian Sea. Deep-Sea Res II 45:2369-2403

Sorokin Yu I, Kopylov AI, Mamaevea NV (1985) Abundance and dynamics of microplankton in the central tropical Indian Ocean. Mar Ecol Prog Ser 24:27-41

Strickland JDH, Parsons TR (1968) A practical handbook of seawater analysis. Bull Fish Res Board Can, Ottawa

Sündström B, Janekarn V, Hylleberg J, Boonruang P (1987) Annual pelagic primary production with notes on physical and chemical variables at Phuket, the Andaman Sea, Thailand. Phuket Mar Biol Cent Res Bull 46:1-18

Thomsen HA (1988) An electron microscopical study of marine loricate choanoflagellates: Nannoeca minuta (Leadbeater) gen. et comb. n. and Stephanoeca cupula (Leadbeater) comb. n. Zool Scr 17:315-323

Thomsen HA, Boonruang P (1983a) Ultrastructural observations on marine choanoflagellates (Choanoflagellida, Acanthoecidae) from the coast of Thailand: species of Apheloecion gen.nov. J Plankton Res 5:739-753

Thomsen HA, Boonruang P (1983b) A microscopical study of marine collared flagellates (Choanoflagellida) from the Andaman Sea, SW Thailand: species of Stephanacantha gen.nov. and Platypleura gen.nov. Protistologica 19: $193-214$

Thomsen HA, Boonruang P (1984) A light and electron microscopical investigation of loricate choanoflagellates (Acanthoecidae, Choanoflagellida) from the Andaman Sea, SW Thailand: species of Cosmoeca gen.n. Zool Scr 13:165-181

Thomsen HA, Moestrup $\varnothing$ (1983) Electron microscopical investigations on two loricate choanoflagellates (Choanoflagellida), Calotheca alata gen, et sp.nov. and Syndetophyllum pulchellum gen. et sp.nov. from Indo-Pacific localities. Proc R Soc Lond B 219:41-52 
Utermöhl H (1958) Zur Vervollkommnung der quantitativen Phytoplankton Methodik. Mitt Int Ver Limnol 9:1-38

Veldhuis MJW, Kraay GW, VanBleijswijk JDL, Baars MA (1997) Seasonal and spatial variability in phytoplankton biomass, productivity and growth in the northwestern Indian Ocean: the southwest and northeast monsoon, 1992-1993. Deep-Sea Res 44:425-449

Westeyn FJ, Ilahude AG, MA Baars (1990) Nutrient distribution in the upper $300 \mathrm{~m}$ of the eastern Banda Sea and northern Arafa Sea during and after the upwelling season, August and February 1985. Neth J Sea Res 25: $449-464$

Wium-Andersen S (1977) Primary production in waters

Editorial responsibility: Otto Kinne (Editor),

Oldendorf/Luhe, Germany around Surin Islands off the west coast of Thailand. Phuket Mar Biol Cent Res Bull 16:1-4

Woods JD, Wiley RL (1972) Billow turbulence and oceanic microstructure. Deep-Sea Res 19:87-121

Woodward EMS, Rees AP, Stephens JA (1999) The influence of south-west monsoon upon the nutrient biogeochemistry of the Arabian Sea. Deep-Sea Res II 46:571-591

Yesaki M, Jantarapagdee P (1981) Wind stress and sea temperature changes off the west coast of Thailand. Phuket Mar Biol Cent Res Bull 28:27-41

Zubkov MV, Sleigh MA, Tarran GA, Burkill PH, Leakey RJG (1998) Picoplanktonic community structure on an Atlantic transect from $50^{\circ} \mathrm{N}$ to $50^{\circ} \mathrm{S}$. Deep-Sea Res I 45:1339-1355

Submitted: July 19, 2003; Accepted: January 15, 2004

Proofs received from author(s): April 23, 2004 